\title{
Estimation of potential groundwater recharge by a drywell in sandy clay soil
}

\section{Estimativa de recarga potencial de aquífero promovida por poço de infiltração em solo arenoso}

\author{
Eliane Aparecida Justino'* (1), Moisés Furtado Failache² (i) \& Ademir Paceli Barbassa² (1) \\ ${ }^{1}$ Universidade Federal do Catalão, Catalão, GO, Brasil \\ ${ }^{2}$ Universidade Federal de São Carlos, São Carlos, SP, Brasil \\ E-mails: eliane_justino@ufg.br (EAJ),moisesfailache@hotmail.com (MFF), barbassa@ufscar.br (APB)
}

Received: July 20, 2020 - Revised: November 16, 2020 - Accepted: November 16, 2020

\begin{abstract}
We estimated the potential groundwater recharge $\left(R_{\text {poo }}\right)$ of a drywell that receives, temporarily stores, and infiltrates direct surface runoff from a contribution area $\left(180.5 \mathrm{~m}^{2}\right)$ comprising a roof and a cemented floor. The $R_{\mathrm{pot}}$ for traditional rainwater management and for similar contribution area but covered with grass was also estimated for comparison. Our methodology involved the use of water budget equation, monitoring of rainfall and soil water content up to $1.92 \mathrm{~m}$ depth, estimation of drywell overflow using the modified Puls model, and determination of actual evapotranspiration using water stress coefficient in 2017 and 2018. Results revealed that the $R_{\text {pot }}$ for drywell was $83.3 \%$ of the precipitated volume, 2.22 times higher than that of the grass-covered area $(37.6 \%)$ given the increased area for evapotranspiration in the latter. In turn, the traditional urban drainage system did not demonstrate potential of groundwater recharge. Therefore, the drywell contributes significantly to groundwater recharge apart from serving as local flood control.
\end{abstract}

Keywords: Drywell; Low-impact development; Best management practices; Artificial groundwater recharge.

\section{RESUMO}

Foi estimada a recarga potencial do aquífero (Rpot) promovida por um poço de infiltração que recebe, armazena temporariamente e infiltra o escoamento superficial direto de uma área de contribuição $\left(180.5 \mathrm{~m}^{2}\right)$ constituída de telhado e piso cimentado. Para servirem de comparação, a Rpot, também, é considerada nios casos em que o escoamento superficial direto é direcionado para um sistema convencional de drenagem água pluvial e acontece em uma área de contribuição semelhante, mas com cobertura gramada, A metodologia envolveu o uso da equação de balanço hídrico, monitoramento da precipitação e do conteúdo de água no solo até $1.92 \mathrm{~m}$ de profundidade, estimativa do transbordamento do poços de infiltração usando o modelo Puls modificado e determinação da evapotranspiração real usando o coeficiente de estresse hídrico nos anos de 2017 e 2018 . A Rpot considerando o poço de infiltração foi de $83.3 \%$ do volume precipitado, 2.22 vezes maior que o da área coberta por grama (37.6\%), justificado pelo aumento da área para evapotranspiração neste ultimo caso. Por sua vez, o sistema tradicional de drenagem urbana não demonstrou potencial de recarga de água subterrânea. Portanto, o poço de infiltração contribui significativamente para a recarga do aquífero, além de servir como controle local de inundações.

Palavras-chaves: Poço de infiltração; Desenvolvimento de baixo impacto; Melhores práticas de gerenciamento; Recarga artificial de aquífero. 


\section{INTRODUCTION}

The use of traditional urban drainage system that disposes of surface runoff as quickly as possible is problematic because it is inefficient and unsustainable (Urbonas \& Stahre, 1993; Tavares et al., 2018; Jung \& Kim, 2020). In response to this problem, compensatory techniques, also known as best management practices (BMPs) or low impact development techniques, were proposed in the USA since 1970 (Ahiablame et al., 2012; Fletcher et al., 2015).

According to Petrucci \& Tassin (2015) and Wang \& Wang (2018) compensatory techniques facilitate the retention, storage, and infiltration of overland flow as close as possible to where it was generated, without the surface runoff being downstream. These techniques thus prevent overloading of drainage infrastructure as well as reduces the pollutant transport and siltation of water bodies. If well designed, they also prevent groundwater pollution (Shon et al., 2013; Mai et al., 2018) and mosquito proliferation (Moruzzi et al., 2014).

Drywell is a compensatory technique that is becoming popular because it requires small areas for implantation and is easily integrated in urban environments. Furthermore, this technique controls flooding in runoff source areas and contributes to potential groundwater recharge in urban environments (Gobel et al., 2004; Sasidharan et al., 2018) locally and indirectly (Lerner et al., 1990; Beekman \& Xu, 2003).

Potential groundwater recharge $\left(R_{\text {pot }}\right)$ refers to the part of precipitation or other water source that infiltrates the soil and percolates below the root zone and may or may not reach the saturated zone (Rushton, 1988; Snyder et al., 1994). $R_{\text {pot }}$ can be estimated by several methods (e.g., the use of numerical models, tracers, water table fluctuation, and water budget); the appropriate method to be used depends on the objective, on the temporal and spatial scale, and on data availability (Sharma, 1986). Water budget is one of the most commonly used method due to its simplicity, and it can be applied in different soil conditions and spatio-temporal scales (Snyder et al., 1994; Soubie et al., 2016; Delle Rose et al., 2018). However, presents as main limitation a high degree of uncertainty in obtaining equation parameters (Scanlon \& Cook, 2002; Hofmann et al., 2014; Munier \& Aires, 2018). Therefore, for a good $R_{\text {pot }}$ estimation promoted by drywell is essential to understand the potential sources of uncertainties, what influence the magnitude of water budget parameters and the main methods limitations.

Rainfall is the only water source of drywells, and depends on mainly the temperature, solar radiation, temporal distribution, evaporation of water bodies, evapotranspiration, topography and air humidity (Ward \& Trimble, 2003). The monitoring of this variable is carried out by raingauges, pluviographs, meteorological radars and satellites, and the most used are pluviometers and pluviographs. The accuracy and quality of rainfall measurements depends on the instrument calibration and installation (e.g., should be considered a protection against strong winds should and a distance from obstacles to prevent oblique rain from falling into the rain gauge) (Bogino, 2014).

Most of rain that falls over buildings or other urban surfaces become direct surface runoff, which is the main input of drywells, and is affected by intensity and duration of rainfall, area and shape of the basin, soil infiltration capacity, topography of the basin, roughness, soil cover and hydraulic constructions (e.g. river canalization or rectification) (Silva et al., 2010). The runoff can be estimated experimentally using traps or flow meters, which presents good accuracy, but are expensive and time consuming, and using Rational Method and empirical formulas that present a high degree of uncertainty, which can result in a low accuracy of estimation (Hellman et al., 2018). To improve the rational method and empirical formulas input data and estimations is essential to obtain experimentally and onsite data to compare both results.

Infiltration is one of the most important components in drywells water budget, because it controls and separates runoff water from that available for groundwater recharge. The magnitude of the infiltration depend on soil infiltration rate, which is a function of soil texture, compaction, initial moisture, porosity, hydraulic conductivity and structure (Failache \& Zuquette, 2018). In general, infiltration can be determine by empirical and physical equations, laboratory and on site methods. However, the methods have as assumption that only vertical water movement occurs during infiltration at great depths, thus, horizontal movement is not represented (King, 1992); the application is expensive for large areas and does not describe all infiltration conditions (Sonaje, 2013); the work scale affects directly the infiltration response; and soil heterogeneity it has a strong effect on the predictions and scaling space-time relationships (Morel-Seytoux, 1988).

The evapotranspiration is the main output parameter in water budget equation, and represent the process of transferring moisture from the soil to the atmosphere by evaporation of water and transpiration from plants, and it is affected by relative air humidity, temperature, wind speed, solar radiation, barometric pressure, plant physiological conditions and initial soil moisture conditions (Linsley et al.,1982). In addition, the size of the evaporating surface, physical conditions of neighbouring area, water salinity, and soil composition and texture also affects evapotranspiration (Granata et al., 2020). The methods used to estimate evapotranspiration in a basin are mainly empirical equations based on climatic data and lysimeters. The evapotranspiration estimation by different empirical equations, in general, do not show the same results, and the difference can be more than 100\% in some cases (Feng et al., 2016). This variability occurs because those equations were developed for different soil and climatic conditions than they were applied.

The soil water storage represent the moisture variation during the year. Generally, indirect methods such as tensiometers, resistance blocks and psychrometers are used to determine soil moisture variation, and the measurement precision depends on the instrument calibration and installation (Schwartz et al., 2016). To obtain soil water storage, it is necessary to know the soil moisture profile, but moisture is not uniform with depth (Libardi, 2005). Mathematically, the soil water storage is the area under the moisture profile curve, and no analytical solution is found it, thus only can be obtained by numerical integration.

Despite water budget simplicity and uncertainties related to parameters determination and $\mathrm{R}_{\text {pot }}$ estimation, this equation has been used frequently to analyse the effects of other compensatory drainage techniques (e.g. infiltration trenchs) on the urban hydrological cycle, and several authors found out that those techniques play an important role in groundwater recharge (e.g. 
Gobel et al., 2004; Wang et al., 2014; Feng et al., 2016). Although compensatory techniques are recognized worldwide as an important groundwater recharge source (Edwards et al., 2016), a few studies have analysed drywell performance to quantify experimentally its potential contribution in groundwater recharge (Sasidharan et al., 2018). In Brazil, drywells were investigated in different type of soils and infiltrate rates by Reis et al. (2008), Carvalho (2008, 2013), Reis \& Ilha (2014), Lucas et al. (2015), Barbassa et al. (2014) and Ferreira et al. (2018). They recognized the role of drywell in groundwater recharge in urban environments; however, they did not quantify its capacity to contribute to such process.

In this context, the main objective of this work was to quantify the Rpotpromoted by one drywell, which is used to manage direct surface runoff (DSR) generated in an impervious area of a building located in University of São Carlos. In addition, the Rpot promoted by the drywell considering different return period was compared with other stormwater management strategies. The Rpot estimation was carried out applying the water budget equation in a soil with high infiltration rates and considered onsite rainfall and soil moisture monitoring, estimation of evapotranspiration, DSR and drywell overflow, field and laboratory works to determine soil hydraulic and physical characteristics.

\section{MATERIALS AND METHODS}

\section{Study area}

The study area is located in the northern part of the Federal University of São Carlos (UFSCar) (Figure 1) situated in the state of São Paulo, southern Brazil, with central coordinates $47^{\circ} 52^{\prime} 45.3^{\prime \prime} \mathrm{W}$ and $21^{\circ} 58^{\prime} 50.3^{\prime \prime} \mathrm{S}$ (Instituto Brasileiro de Geografia e Estatistica, 2012). This region presents a temperate climate with an average temperature of $19.6^{\circ}$ and an annual rainfall of $1512 \mathrm{~mm}$ (Centro de Pesquisas Meteorológicas e Climáticas Aplicadas à
Agricultura, 2018). The average altitude is $860 \mathrm{~m}$, and the relief is characterized by smooth hills. The soil was originated from the transport of the residuals from the Itaqueri Formation (sandstones, siltstones and claystones), and it is characterized by a thickness greater than 12 meters, a homogenous reddish yellow color and sandy clay texture (Figure 1) (Pejon, 1987; Failache \& Zuquette, 2018), and by high infiltration rates with an average of $350 \mathrm{~mm} / \mathrm{h}$ (Ferreira et al., 2018). The water table within a year varies between 9.8 and $12.0 \mathrm{~m}$ in relation to soil surface (Sírio, 2014).

\section{Experimental setup and drywell design}

The experimental area (Figure 2), consists of contribution area (half of the Biopolymers Laboratory's metal roof and a cemented floor), with a total area of $180.5 \mathrm{~m}^{2}$, the drywell named PGHidro where DSR from the contribution area (basin area) is disposed of and drywell influence area (Item 2.5.1) totalizing $21.36 \mathrm{~m}^{2}$.

Figure 3 a shows the structural details of the PGHidro, which consists of four perforated concrete rings with $1.10 \mathrm{~m}$ internal diameter and $0.50 \mathrm{~m}$ height, arranged on concrete blocks $(12 \mathrm{~cm} \times 22 \mathrm{~cm} \times 6 \mathrm{~cm})$ that serve as base and renders stability to the entire structure. The adoption of those specifications was because the diameter of the used ring is commercial and construction of drywells in São Carlos municipality considered four rings. A $6 \mathrm{~cm}$ gravel layer covered with a geotextile blanket was deposited on the bottom of the rings. The space between the rings and the excavated soil was also filled with gravel, and a geotextile blanket was juxtaposed with the ground (Figure 3b). A perforated cap (Figure 3c) was used to establish a $5 \mathrm{~cm}$ gravel layer over, which a geotextile blanket was fixed by another $10 \mathrm{~cm}$ gravel layer. Based on PGHidro dimensions, the storage volume was $2.26 \mathrm{~m}^{3}$, thus meeting the legal specification of $5 \mathrm{~L} / \mathrm{m}^{2}$ proposed by Law 15,958/2011 (São Carlos, 2011), and this drywell volume can storage 30 minutes rainfall events of 9 years of return period.
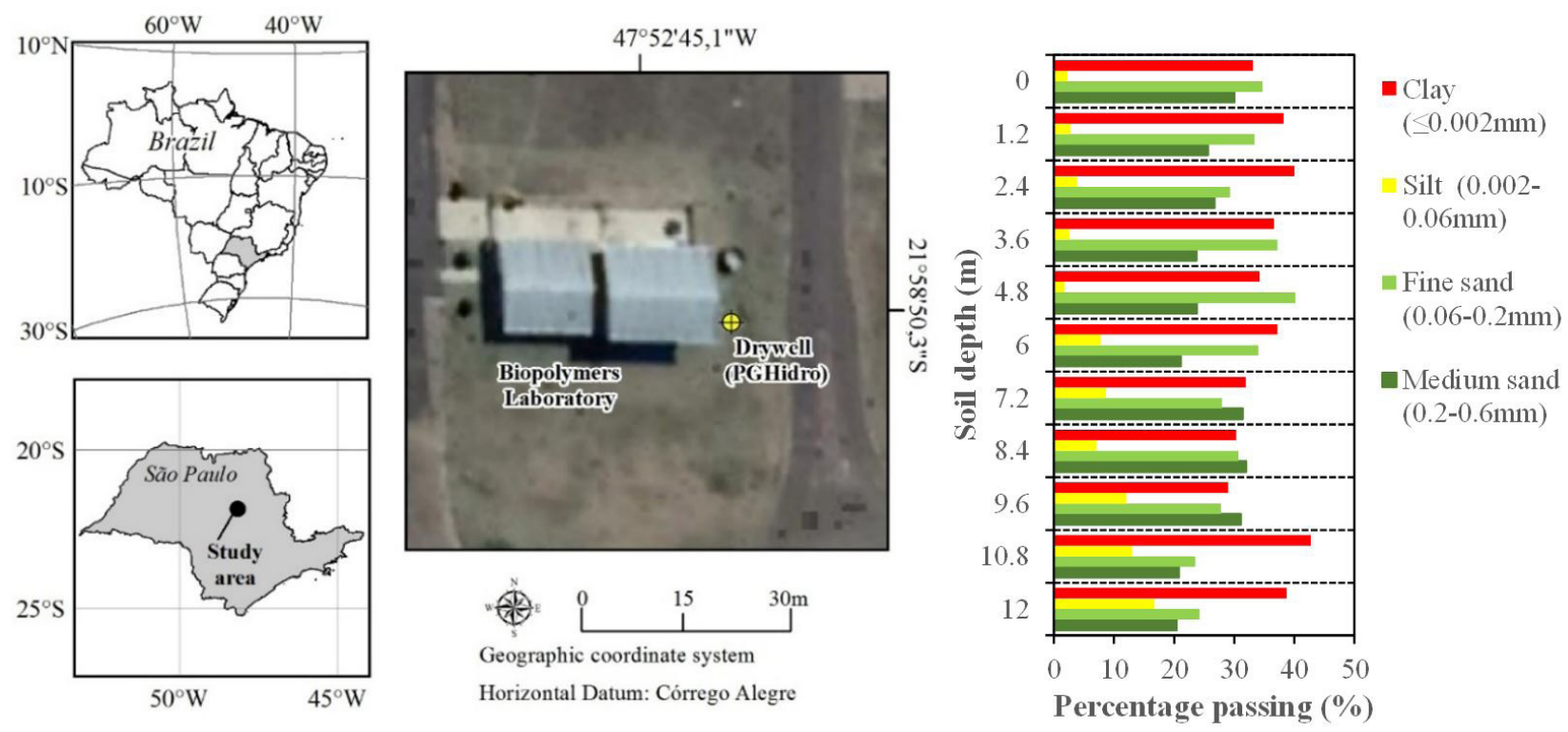

Figure 1. Study area location and soil texture profile, which soil particles are classified based on ABNT (Associação Brasileira de Normas Técnicas, 1995). 


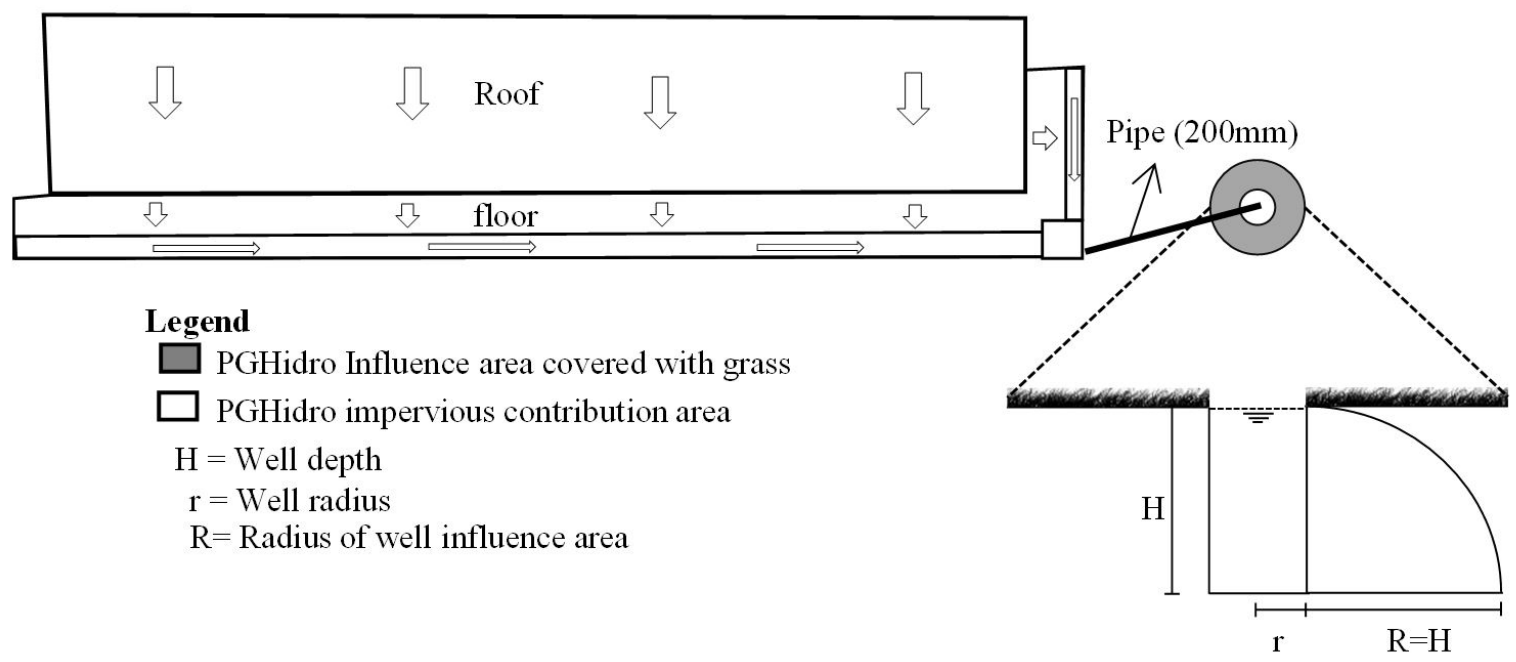

Figure 2. Drywell experimental setup.

a)

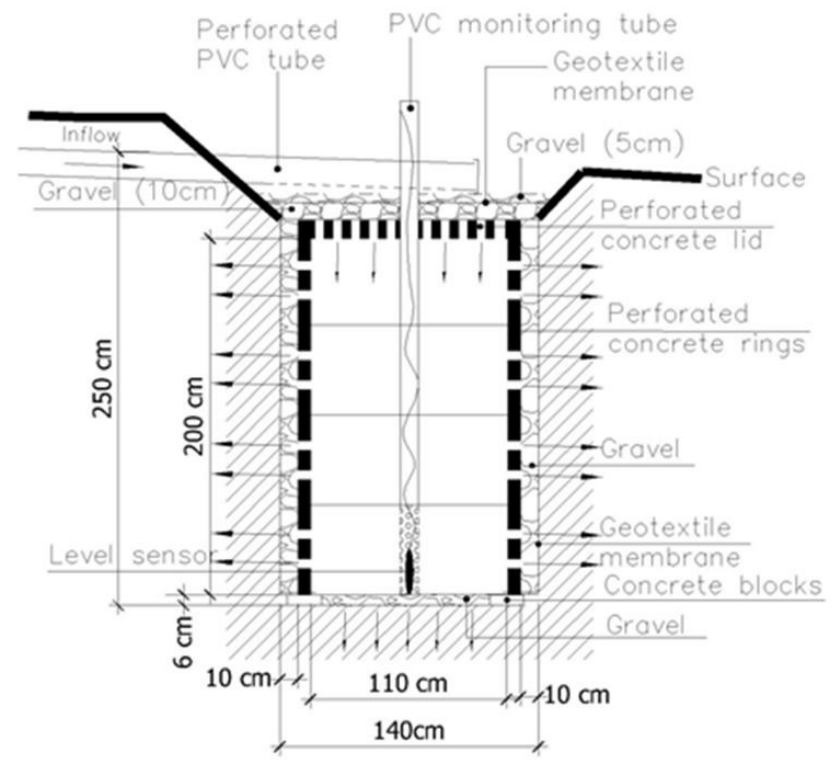

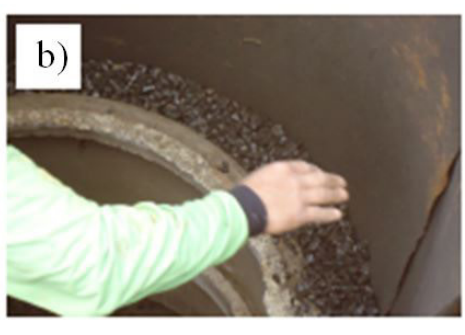

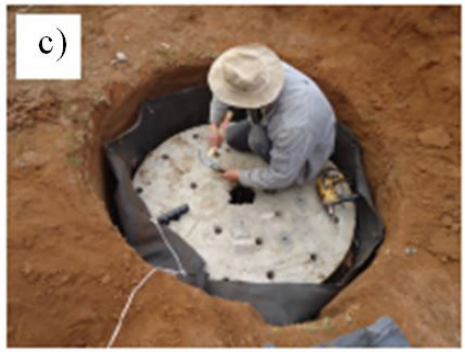

Figure 3. Structural details of the PGHidro: (a) Transverse section; (b) gravel layer between rings and geotextile blanket; and (c) perforated concrete cap. Modified from Ferreira et al. (2018).

\section{Conceptual model}

Figure 4 shows the conceptual model for $R_{\text {pot }}$ from the rainwater management with drywell. The only water input that was considered in conceptual model is rainfall $(\mathrm{P})$, which occurs on the impervious area (contribution area) composed by metal roof and cemented floor of the Biopolymers laboratory, and on the drywell influence area (Equation 1). In the impervious area that is directly connected with the PGHidro, part of the water input is considered hydrological loss because of depression storage (DS) and evaporation (E), and the other part becomes direct surface runoff $\left(\mathrm{DSR}_{\text {roof }+ \text { floor }}\right)$.

The DSR ${ }_{\text {roof }+ \text { floor }}$ is the result of precipitation $\mathrm{P}$ minus

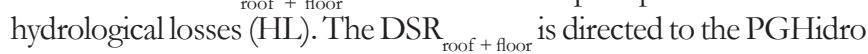
and will infiltrate $\left(\mathrm{I}_{\text {Well }}\right)$ (Equation 2). However, depending on the rainfall intensity and duration, as well as the well's infiltration rates, may occur overflow $\left(\mathrm{O}_{\mathrm{flw}}\right)$, which will be directed to the surface drainage system. On the other hand, in the well influence area, $P$ falls directly into grassy area, but depending on the characteristics of rainfall, interception, depression storage and soil infiltration capacity, part of the water can infiltrate $\left(\mathrm{I}_{\text {grass }}\right)$ (Equation 3) and direct surface runoff $\left(\mathrm{DSR}_{\text {gras }}\right)$ can generated, which is directed to the surface drainage system.

After the rainfall event ends, in the well influence area and depth, the infiltrated water may leave the system by evapotranspiration (ET) and subsurface flow $\left(\mathrm{R}_{\text {sub }}\right)$, which are function of climate, soil and landscape characteristics. In addition, soil water storage $(\Delta \mathrm{h})$ was included in the developed conceptual model to take account its variation. The result of balance input, outputs and change in soil water storage corresponded to the potential groundwater recharge promoted by the drywell. Equation 1 describes the conceptual model, which the magnitude of each parameter is function of local condition, which will be explained as following. 


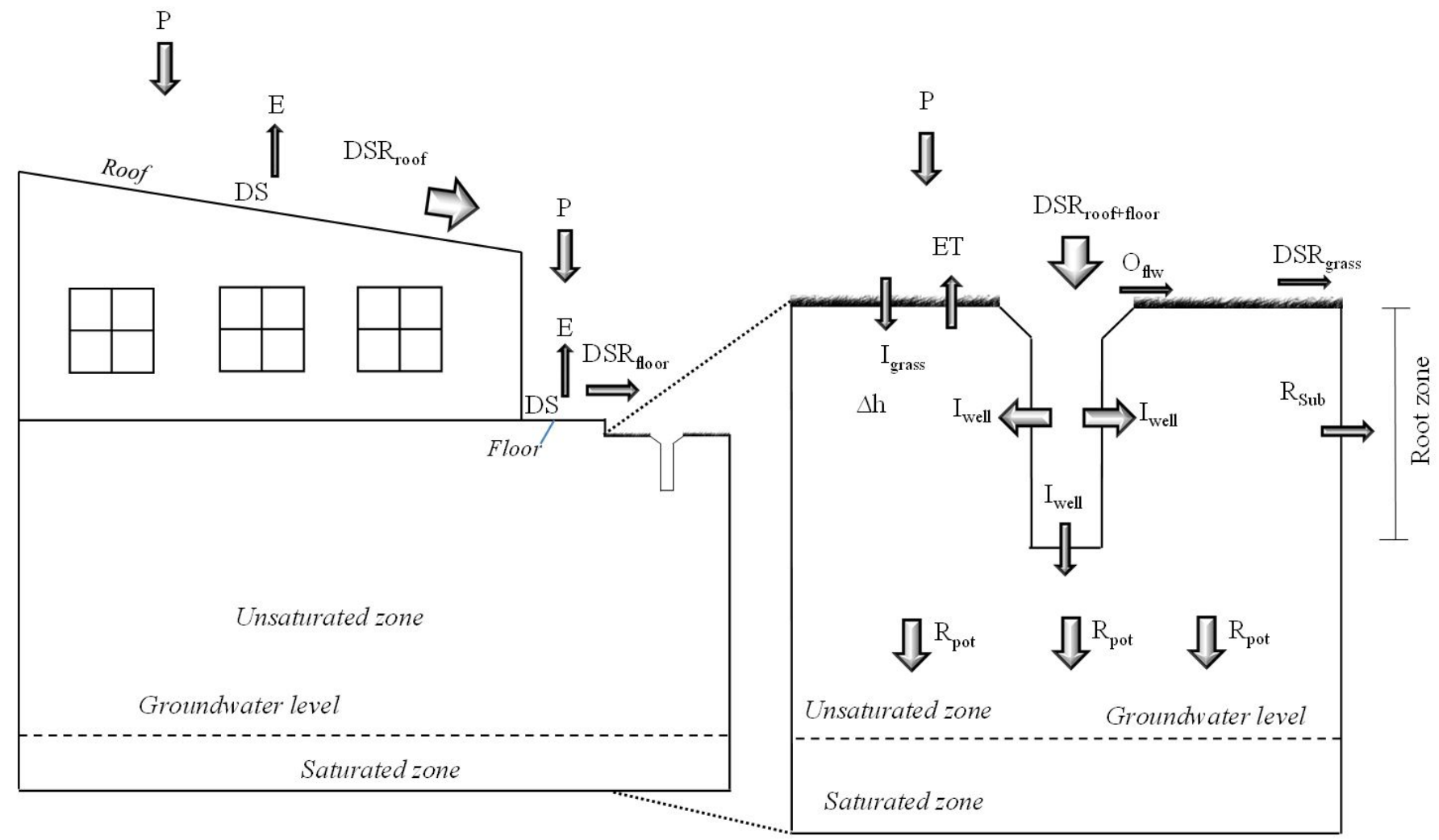

Figure 4. Schematic of the drywell conceptual model.

$R_{\text {pot }}=I_{\text {Well }}+I_{\text {Grass }}-E T-R_{\text {sub }} \mp \Delta h$

Where:

$I_{\text {well }}=\left(D S R_{\text {Roof }+ \text { floor }}-O_{f l w}\right)$

$I_{\text {grass }}=P-D S R_{\text {Grass }}$

Substituting Equations 2 and 3 in Equation 1, we have the global equation (Equation 4) of the water balance and conceptual model of drywell.

$R_{p o t}=\left(D S R_{R o o f+f l o o r}-O_{f l w}\right)+\left(P-D S R_{\text {Grass }}\right)-E T-R_{\text {sub }} \mp \Delta h$

\section{Determination of water budget parameters}

Actual evapotranspiration (ET)

To estimate the ET that occurs in the root zone, which according Christians (1998) correspond $90 \mathrm{~cm}$ for Wild Zoysia, we used the crop coefficient method considering the water stress effect, wherein we multiplied the potential evapotranspiration $(E T)$ by the crop coefficient $\left(K_{c}\right)$ and the coefficient of water stress $\left(K_{\mathrm{s}}\right)$ (Equation 5)

$$
E T=E T_{o} \cdot K_{c} \cdot K_{s}
$$

In São Carlos Region, Marcuzzo et al. (2008) evaluated and compared five different $\mathrm{ET}_{0}$ estimation methods with real evapotranspiration data (lysimeter), and they found out that Class A Tank estimations showed a better agreement with lysimeter measurements. Therefore, $\mathrm{ET}_{\mathrm{o}}$ was estimated by the empiric method of Class A Tank that is based on the proportionality between evaporation of the Tank (EV) and $\mathrm{ET}_{\mathrm{o}}$, in which both depends exclusively of meteorological conditions. The conversion of $\mathrm{EV}$ to $\mathrm{ET}_{\mathrm{o}}$ depends on the proportionality coefficient namely the tank coefficient $\left(K_{p}\right)$, which is related to relative air humidity, wind speed and distance of the Class A tank from the area without grass cover (Allen et al., 1998).

ET was estimated by using daily data monitored at the Laboratory of Hydraulics and Computing (LHC)-IAB Station located $20 \mathrm{~km}$ away from the study area with coordinates $205802 \mathrm{~m}$ and $7543956 \mathrm{~m} \mathrm{~S}$ (Datum WGS 1984, Zone 23). ET was calculated by multiplying the $\mathrm{EV}$ with the pan coefficient $\left(\mathrm{K}_{\mathrm{p}}\right)$, as follows:

$$
E T_{o}=K_{p} \cdot E V
$$

According to Allen et al. (1998), there are two $K_{\mathrm{p}}$ calculation cases: (a) the pan is placed on dry soil and surrounded by some grass or crop and (b) the pan is situated on grass and distant from a dry soil, which is the case for Class A evaporation pan in the LHC-IAB Station. Therefore, $K_{\mathrm{p}}$ was obtained as follows:

$$
\begin{aligned}
& K_{p}=0.108-0.0286 \cdot u_{2}+0.0422 \cdot \ln (F E T)+ \\
& 0.1434 \cdot \ln \left(R_{\text {Hmean }}\right)-0.000631 \cdot \ln (F E T)^{2} \cdot \ln \left(R_{\text {Hmean }}\right)
\end{aligned}
$$

where $u_{2}$ is the daily average wind speed at $2 \mathrm{~m}$ height, ranging from $1 \mathrm{~m} / \mathrm{s}$ to $8 \mathrm{~m} / \mathrm{s} ; R_{\text {Hmean }}$ is the daily mean relative humidity, ranging from $30 \%$ to $84 \%$; and FET is the distance of the Class A tank from the area without grass cover, varying from $1 \mathrm{~m}$ to 
$1000 \mathrm{~m}$ (in this work, FET was considered $100 \mathrm{~m}$ ). $\mathrm{u} 2$ and $\mathrm{R}_{\text {Hmean }}$ were measured by a bearing shell anemometer of Young company, model 05103 with precision of $0,3 \mathrm{~m} / \mathrm{s}$, and a Campbell Scientific psychrometer, model HC2S3-L with precision of $\pm 0.8 \% \mathrm{RH}$ with standard configuration settings (at $23^{\circ} \mathrm{C}$ ), respectively, at the LHC-IAB Station.

$K_{\mathrm{c}}$ relates the $\mathrm{ET}_{\mathrm{o}}$ in field to the real evapotranspiration of a given crop measured under ideal laboratory condition. This coefficient depends only on crop transpiration characteristics, which is function of climatic and wetting conditions. The vegetation type (crop) that cover influence area of drywell is warm season turf grass (Wild Zoysia). The $K_{\mathrm{c}}$ value adopted was 0.85 , which represent the average value of crop development stages during the year (Doorenbos \& Pruitt, 1997; Allen et al., 1998).

$K_{\mathrm{s}}$ represents the available soil water in the root zone, wherein $K_{\mathrm{s}}<1$ indicates that limited amount of water is available for plants and $K_{\mathrm{s}}=1$ indicates that water is readily available for consumption. This correction is necessary given that crop evapotranspiration cannot be greater than the soil water availability. According to Allen et al. (1998), $K_{\mathrm{s}}$ is calculated as follows:

$$
K_{s}=\frac{T A W-D_{r}}{T A W-R A W} \rightarrow \text { For }: D_{r}>R A W
$$

where $\mathrm{D}_{\mathrm{r}}(\mathrm{mm})$ is the water depletion rate, TAW $(\mathrm{mm})$ is the total available soil water, $\varrho$ is the TAW fraction that a crop can extract water without suffering hydric stress, and RAW ( $\mathrm{mm})$ is the soil water amount readily available for extraction. The parameters are calculated as follows:

$$
R A W=\rho \cdot T A W
$$

$$
T A W=1000 \cdot\left(\theta_{f_{c}}-\theta_{w p}\right) \cdot Z_{f}
$$

where $\theta_{\mathrm{fc}}\left(\mathrm{cm}^{3} / \mathrm{cm}^{3}\right)$ is the volumetric moisture content at field capacity, $\theta_{\text {wp }}\left(\mathrm{cm}^{3} / \mathrm{cm}^{3}\right)$ is the volumetric moisture content at wilting point, and $Z_{\mathrm{f}}(\mathrm{m})$ is the root zone depth.

$$
D_{r, i}=D_{r, i-1}-(P-D S R)_{i}-I r_{i}-C R_{i}+E T_{c, i}+P E_{i} \rightarrow 0 \leq D_{r} \leq T A W
$$

where $D_{\mathrm{r}, \mathrm{i}}(\mathrm{mm})$ is the water depletion on day $\mathrm{i} ; D_{\mathrm{r}, \mathrm{i}-1}(\mathrm{~mm})$ is the water content on the previous day, which the initial depletion as given by Equation 9; $P_{\mathrm{i}}(\mathrm{mm})$ is the rainfall on day $\mathrm{i} ; \operatorname{DSR}_{\mathrm{i}}(\mathrm{mm})$ is the DSR on day $i ; r_{i}(\mathrm{~mm})$ is the irrigation on day $i$ (this parameter was not considered because the study area is not irrigated); $C R_{1}$ $(\mathrm{mm})$ is the capillary rise from the saturated zone to the root zone (this parameter was not considered because the root zone is more than $1 \mathrm{~m}$ away from the saturated zone); $E T_{\mathrm{c}, \mathrm{i}}(\mathrm{mm})$ is the crop evaporation on day $i$; and $P E_{i}(\mathrm{~mm})$ is the loss of water out of the root zone by percolation given by Equation 13 .

$$
D_{r, i-1}=1000 \cdot\left(\theta_{f c}-\theta_{i-l}\right) \cdot Z_{f}
$$

where $\theta_{\mathrm{i}-1}\left(\mathrm{~cm}^{3} / \mathrm{cm}^{3}\right)$ is the mean soil water content.

$$
P E_{i}=(P-D S R)_{i}-E T_{c, i}-D_{r, i-1} \geq 0
$$

When soil moisture is below field capacity, deep percolation does not occur $\left(D_{\mathrm{r}, \mathrm{I}}>0\right.$ and $\left.P E_{\mathrm{i}}=0\right)$.
The data required to calculate water stress coefficient were obtained from Allen et al. (1998) and from field and laboratory works, wherein the values for $Z_{\mathrm{f}}, \varrho, \theta_{\mathrm{fc}}$, and $\theta_{\text {wp }}$ are $0.60,0.45$, 0.19 , and 0.10, respectively. From fieldwork, it were obtained soil undisturbed samples in four depths, $0.20 \mathrm{~m}, 0.60 \mathrm{~m}, 1.0 \mathrm{~m}$ and $2.0 \mathrm{~m}$ considering triplicate, which were extracted from a trench $30 \mathrm{~m}$ away to the PGHidro to determine in laboratory $\theta_{\mathrm{fc}}$ and $\theta_{\mathrm{wp}}$. The $\theta_{\mathrm{fc}}$ and $\theta_{\mathrm{wp}}$ were obtained from soil water retention curve that was determined by filter paper method, and their final value corresponded the average value of all sampled depths.

\section{Monitoring of water storage variation $(\Delta \mathrm{h})$}

The EnviroScan capacitance probes from March 8 to October 8 in 2017 monitored the volumetric soil moisture around PGHidro. These probes measured the soil water content indirectly by using the method of frequency domain reflectometry, wherein the soil dielectric constant was determined to obtain the soil moisture from a calibration curve determined in laboratory. The probe sensor has a resolution of $0.1 \mathrm{~mm}$ of soil moisture and have a coefficient of variation of $0.1 \%$. Based on the hypothesis that soil is homogeneous and isotropic, the water flow around the drywell was considered equal in any direction, and because of that, the probes were installed in only one direction.

The Figure 5 shows the arrangement of the four probes located on the same line extended radially from the drywell centre, which were labelled as Probe 1, Probe 2, Probe 3, and Probe 4 and installed with 9, 7, 7, and 6 sensors, respectively. Although the probe extension is less than the well depth, it was possible to monitors the entire root zone $(90 \mathrm{~cm})$. It is important to point out that, the sensors near at soil surface are set higher in elevation than the drywell perforated concrete cap about $37.5 \mathrm{~cm}$ as it appears from Figure 5. This means that the probes were able to measure water moisture variation of superficial layer of drywell influence area. In addition, Figure $5 \mathrm{~b}$ and Figure $5 \mathrm{c}$ shows respectively the schematic moistening bulb representing soil water content around the PGHidro before and after a controlled experiment representing maximum rainfall intensity, in which the drywell was filled with water to the top during 1 hour and 30 minutes, and water discharge was kept constant. The determination of the moistening bulb was based on the monitored water content values that was interpolated using nearest neighbour interpolator in Surfer 9 (free trial version).

For $\Delta \mathrm{h}$ estimation up to a depth $\mathrm{L}$, the trapezoidal numerical integration rule (Libardi, 2005) was used as given by Equation 14 .

$$
h_{L}=\int_{0}^{L} \theta(Z) d Z \cong\left[0.5 \theta\left(Z_{0}\right) \Delta Z_{0}+\sum_{i=1}^{n-1} \theta\left(Z_{i}\right) \Delta Z_{i}+0.5 \theta\left(Z_{n}\right) \Delta Z_{n}\right]
$$

where $\theta$ is the soil water volumetric content and $Z$ is the sensor depth.

$\Delta \mathrm{h}$ was determined up to $2 \mathrm{~m}$ depth by calculating the difference between the values obtained at $0 \mathrm{~h}$ and those obtained at $24 \mathrm{~h}$ of a particular day. Within the monitored period, the highest and lowest storage values were -15.9 and $15.8 \mathrm{~mm}$ for March and October, respectively. The cumulative $\Delta b$ was only $-5.50 \mathrm{~mm}$; if it were calculated from March 2017 to March 2018, this variation could be smaller, because water variation of final 
a)

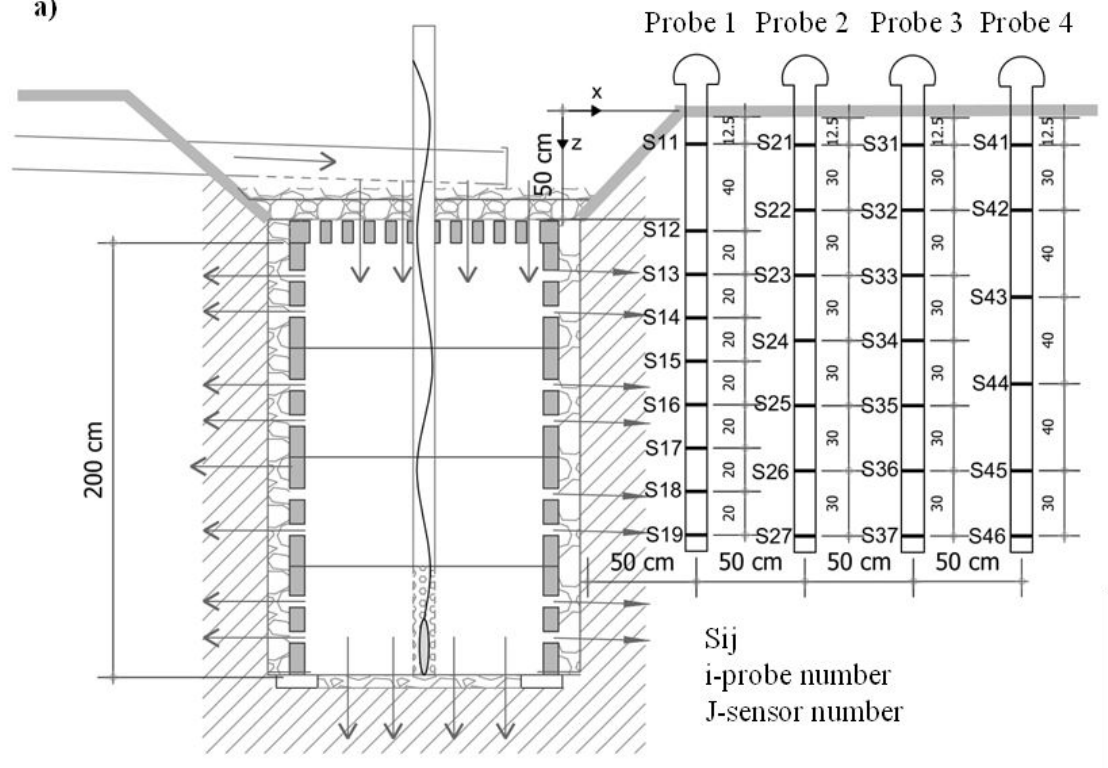

b) Distance to drywell $(\mathrm{cm})$

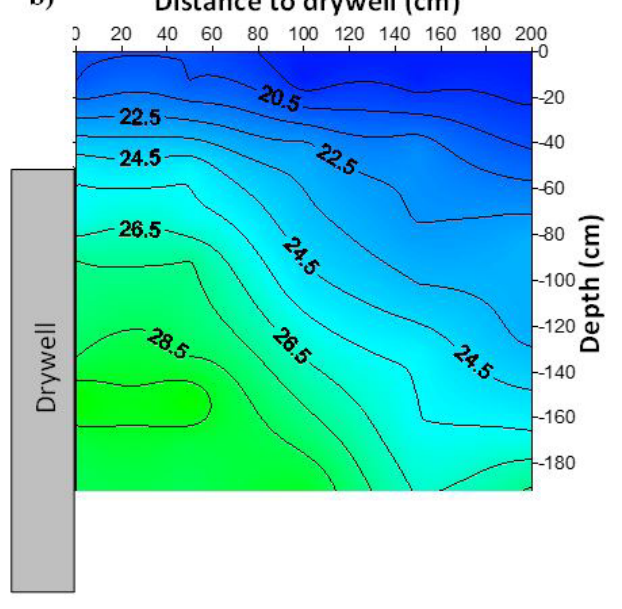

c) Distance to drywell $(\mathrm{cm})$

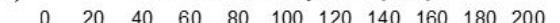

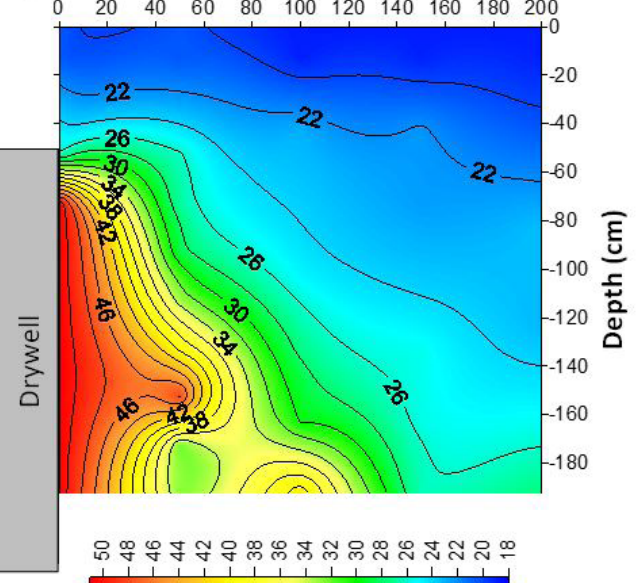

Water content (adimensional)

Figure 5. (a) Arrangement of the probes installed around PGHidro; (b) soil moisture profile around PGHidro before maximum rainfall test; (c) soil moisture profile around PGHidro after maximum rainfall test.

condition tends to be similar to the initial condition (Justino, 2019). For this reason, when comparing the magnitude of rainfall and evapotranspiration, $\Delta b$ was neglected.

\section{Rainfall (P)}

A digital tipping bucket rain gauge (model ARG100 - sensors QMR102), with an accuracy of $1 \%(<24 \mathrm{~mm} / \mathrm{h})$ and $5 \%(>120 \mathrm{~mm} / \mathrm{h})$ and sensivity of $0.2 \mathrm{~mm}$, collected the $P$ data every $2 \mathrm{~min}$. This device was installed at the UFSCar Meteorological Station located $500 \mathrm{~m}$ from the drywell. The validation of rainfall data was carried out comparing the rain gauge measurements with a pluviograph (analogical model) and pluviometer installed less than 10 meters away.

Direct surface runoff (DSR), subsurface flow $\left(\mathrm{R}_{\mathrm{sub}}\right)$ and Overflow $\left(\mathrm{O}_{\text {flw }}\right)$

The DSR were determined by multiplying the rainfall $P$ with surface runoff coefficient $C$, which is the ratio between
DSR and P. The determination of Biopolymers Laboratory's roof and floor $\left(\mathrm{C}_{\text {roof }+ \text { floor }}\right)$ was based on Tecedor et al. (2015), who considered seven rainfall events and determined an average value of DSR from a metal roof and cemented floor $\left(1,747 \mathrm{~m}^{2}\right)$ of the Physiotherapy building, located $50 \mathrm{~m}$ away from Biopolymers building. The authors used a spillway to monitor DSR volume that was directed to an infiltration plan, and monitored rainfall using the same rainfall gauge described in Item 2.4.3.

The average obtained $\mathrm{C}_{\text {roof }+ \text { floor }}$ was 0.83 , which is according to ASCE (American Society of Civil Engineers, 1992) data, that for metal roof and the cemented floor area the DSR coefficient varies from 0.75 to 0.95 and 0.70 to 0.95 respectively. However, because Physiotherapy building is older than Biopolymers building, it was adopted 0.90 as $\mathrm{C}_{\text {roof }+ \text { floor }}$ because older surfaces show greater hydrological losses due to increased roughness (Wang \& Yang, 2018). The generated DSR in drywell influence area covered with grass is calculated considering the grass runoff coefficient $\left(\mathrm{C}_{\text {grass }}\right)$ equal to 0.10 (American Society of Civil Engineers, 1992). This value was adopted, because the drywell influence area presents sandy clay soil, with a slope $<2 \%$, has low interception capacity and high infiltration rates. 
$R_{\text {sub }}$ represents the quantity of infiltrated water that flows laterally in the unsaturated zone, at the root depth, towards to drainage channels without recharging the groundwater (Fetter, 2001). The essential condition for the occurrence of subsurface flow is that lateral hydraulic conductivity has to be greater than vertical hydraulic conductivity, where magnitude and direction is function mainly of terrain gradient, soil characteristics. Therefore, $R_{\text {sub }}$ will depend on the presence of low permeability layers after the infiltration surface, which can be a soil horizon with high clay percentage and high soil density values or a soil interface with altered or unaltered rock; and slope with a determined degree that allows the occurrence of $\mathrm{R}_{\text {sub }}$, since steep and flat slopes promotes the occurrence of surface runoff and percolation respectively, therefore reducing $\mathrm{R}_{\text {sub }}$ (Salemi, 2013).

To verify the occurrence of $R_{\text {sub, }}$ a soil survey considering one drilled log located $20 \mathrm{~m}$ from PGHidro was carried out in the study area (Information provided by the Physical Development Office of the Federal University of São Carlos), 2019), however, we did not identify any impermeable layer up to ten meter deep. Besides, slope of the experimental area is less than $2 \%$, groundwater level is around $12 \mathrm{~m}$ (Sírio, 2014) and PHGhidro is more than 600 meters away from drainage channel. Those identified conditions suggests that much of infiltrated water by PGHidro and by its respective influence area do not become $R_{\text {sub }}$, thus, it will be available for groundwater recharge, water storage or evapotranspiration. Because of those reasons, in this study $R_{\text {sub }}$ was neglected in the water budget calculation.

$O_{\text {flw }}$ occurs when water level exceeds $2.5 \mathrm{~m}$, which is the depth of PGHidro. $O_{\mathrm{flw}}$ was determined by analyzing the drywell dimensions and the rainfall data for 2017 and 2018 years. The design rainfall was calculated by using the rain envelope method (Urbonas \& Stahre, 1993) considering the PGHidro dimensions, the saturated hydraulic conductivity of $9.7 \times 10^{-5} \mathrm{~m} / \mathrm{s}$ calibrated by Ferreira et al. (2018), and the rainfall equation for São Carlos region (Barbassa, 1991). The maximum rainfall with $30 \mathrm{~min}$ duration for the 9-year return period was $29.6 \mathrm{~mm}$, corresponding to an intensity of $59.2 \mathrm{~mm} / \mathrm{h}$. In order to evaluate and compare the effect of rainfall return periods on $\mathrm{O}_{\mathrm{fl}_{\mathrm{w}}}$ the drywell were also designed for 5 and 2 rainfall return periods considering 30 minutes of rainfall duration, which the designed rainfall intensity $(\mathrm{mm} / \mathrm{h})$, total rainfall $(\mathrm{mm})$ and drywell depth $(\mathrm{m})$ are respectively $53.1 \mathrm{~mm} / \mathrm{h}$, $26.5 \mathrm{~mm}$ and $2.25 \mathrm{~m}$ and $44.2 \mathrm{~mm} / \mathrm{h}, 22.1 \mathrm{~mm}$ and $1.75 \mathrm{~m}$. Based on these values, rainfall events with 30 min duration and with intensity higher than the designed rainfalls were used to calculate $O_{\text {flw }}$ by using the modified Puls model (Puls, 1928; Cudworth Júnior, 1989). The Puls model is based on the continuity equation shown in Equation 15, which considers the inflow discharge $\left(Q_{\mathrm{i}}\right)$, outflow discharge $\left(Q_{\mathrm{o}}\right)$, overflow discharge $\left(Q_{\mathrm{flw}}\right)$, time variation $(\Delta t)$, and volume variation $\left(V_{2}-V_{1}\right)$, as follows:

$\frac{Q_{i 1}+Q_{i 2}}{2}-\frac{Q_{o 1}+Q_{o 2}}{2}-\frac{Q_{f l w 1}+Q_{f l w 2}}{2}=\frac{V_{2}-V_{1}}{\Delta t}$

Equation 15 was rearranged to calculate the unknown variables, namely, volume, outflow, and overflow discharge in time 2, as follows:

$Q_{i 1}+Q_{i 2}-Q_{o 1}-Q_{f l w l}+\frac{2 V_{1}}{\Delta t}=\frac{2 V_{2}}{\Delta t}+Q_{o 2}+Q_{f l w 2}$ where

$V_{2}=A_{\text {bot_effective }} \cdot W L_{2}$

$Q_{o 2}=K_{s} \cdot A_{b o t_{-} \text {total }}+K s \cdot \pi \cdot D \cdot W L_{2}$

$Q_{f l w 2}=Q_{i 2}-Q_{o m a x}$

wherein $A_{\text {bot_effective }}\left(1.11 \mathrm{~m}^{2}\right)$ is the effective bottom area used for storage water volume calculation, $W L$ is the water level inside the drywell, Ksat is the saturated hydraulic conductivity, $A_{\text {bot_total }}$ $\left(1.54 \mathrm{~m}^{2}\right)$ is the bottom area available for infiltration, $D$ is the drywell diameter, and $Q_{\text {omax }}$ is the maximum outflow discharge referred to as $Q_{\mathrm{o}}$ when WL is at maximum depth. Notice that equation 17 is an approximate version of Darcy equation, because we assume that soil becomes saturated as soon as the infiltration process begins, and there is a unit hydraulic gradient.

Nominating the first term of Equation 16 as Value 1 and substituting Equations 17, 18, and 19 in Equation 16, we obtain

ValueI $=\left(\frac{2 \cdot A_{\text {bot_effective }} \cdot W L_{2}}{\Delta t}\right)+\left(K_{s} \cdot A_{\text {bot_total }}+K s \cdot \pi \cdot D \cdot W L_{2}\right)+\left(Q_{i 2}-Q_{o \max }\right)$

Rewriting Equation 20 to isolate $\mathrm{WL}_{2}$, we get

$W L_{2}=\frac{\text { Valuel }-K_{s} \cdot A_{\text {bot total }}-Q_{i 2}-Q_{o \max }}{\left(\frac{2 \cdot A_{b o t} \text { effective }}{\Delta t}+K_{s} \cdot \pi \cdot D\right)}$

Considering that volume varies with WL, it was calculated interactively $\mathrm{Q}_{\mathrm{o} 2}$ and $V_{2}$ from $W L_{2}$, and then $Q_{\mathrm{o} 2}$ and $V_{2}$ were used in Equation 16 to obtain $Q_{\text {flw } 2}$ for each time interval. At the end, $Q_{\text {flw } 2}$ of all intervals were summed and them divided by the contribution area of PGHidro to obtain $\mathrm{O}_{\mathrm{flw}}$ for each rainfall event

\section{Potential groundwater recharge $\left(\mathbf{R}_{\text {pot }}\right)$}

$R_{\text {pot }}$ was estimated from the water budget equation shown in Equation 4, which was applied in the three stormwater management strategies based on the considerations of Topic 2.4.

\section{Drywell}

The Figure 2 shows the setup for the drywell, whose contribution area includes the roof and floor of the Biopolymers Laboratory. The rainfall $\mathrm{P}$ received by the contribution area becomes the surface runoff $\left(D S R_{\text {roof }+ \text { floor }}=C_{\text {roof }+ \text { floor }} \cdot P\right)$, which drains into the PGHidro. Rainfall also occurred on the PGHidro influence area, and this water will infiltrate the soil. This infiltration is equal to the rainfall $(\mathrm{P})$ minus the $\operatorname{DSR}\left(C_{\text {grass }} \cdot P\right)$. Based on the considerations presented in section $2.4, R_{\text {pot }}$ promoted by the drywell is calculated as follows:

$$
R_{\text {pot }}=C_{\text {conv } 1} \cdot C_{\text {roof }+ \text { floor }} \cdot P+C_{\text {conv } 2} \cdot\left(P-C_{\text {grass }} \cdot P-E T-O_{f l w}\right)
$$

The constant $\mathrm{C}_{\text {conv1 }}$ converts the DSR generated on the roof and floor areas to a water depth value equivalent to the total drywell contribution area (roof area and cemented floor are added to the 
PGHidro influence area). $C_{\text {conv2 }}$ converts the infiltrated value on the drywell influence area to a value equivalent to the total drywell contribution area. These constants were calculated as follows:

$$
\begin{aligned}
C_{\text {convl }} & =\frac{\text { Area }_{\text {roof }+ \text { floor }}}{\text { Area }_{\text {roof }+ \text { floor }}+\text { Area }_{\text {influence }}} \\
C_{\text {conv } 2} & =\frac{\text { Area }_{\text {influence }}}{\text { Area }_{\text {roof }}+\text { floor }+ \text { Area }_{\text {influence }}}
\end{aligned}
$$

where Area $_{\text {roof }+ \text { floor }}\left(\mathrm{m}^{2}\right)$ is equal to $180.5 \mathrm{~m}^{2} ;$ Area $_{\text {influence }}\left(\mathrm{m}^{2}\right)$ corresponds to the moistening bulb area in the projection view, and this area is assumed to reach a distance equal to the well depth, as shown in Figure 2. This area can be justified by Rodio (1965) proposal in the ABGE Bulletin, which empirically states that the horizontal wetting front is equal to the drywell depth, or even by wetting profile determination and analysis. The wetting profile obtained by moisture monitoring from probes (Figure 5) were in agreement with Rodio (1965) statement, which reduced the probability to over or underestimating potential groundwater recharge because the drywell influence area affects directly the evapotranspiration rates. Therefore, with the well radius ${ }^{\circledR}$ being $0.70 \mathrm{~m}$ and depth $(H)$ being $2 \mathrm{~m}$, we have

$$
\text { Area }_{\text {inf luence }}=\pi \cdot(H+r)^{2}-\pi \cdot r^{2}=21.36 m^{2}
$$

\section{Grass covering}

The second rainwater management involves the grasscovered contribution area; the elements of this scenario are shown in Figure 6a.

For this scenario, $R_{\text {pot }}$ was estimated based on the established conditions applied in Equation 4. The potential groundwater recharge is calculated by deducting the evapotranspiration and the DSR generated from the rainfall received by the contribution area, as follows:

$$
R_{\text {pot }}=P-C_{\text {grass }} \cdot P-E T
$$

\section{Drainage conventional system}

In conventional management, DSR is disposed of into a rainwater drainage system, the elements of this scenario are shown in Figure 6b. The contribution area has a $C_{\text {roof }+ \text { floor }}$ equal to 0.9 (American Society of Civil Engineers, 1992); in other words, $90 \%$ of the rainfall becomes a DSR, whereas the remaining water is retained on surface irregularities and eventually evaporated. Therefore, $R_{\text {pot }}$ in this case is practically null.

\section{RESULTS AND DISCUSSION}

\section{Rainfall monitoring}

Figure 7 shows the monthly rainfall data for 2017 and 2018, wherein the total annual values were 1567.2 and $1326.7 \mathrm{~mm}$, respectively. Data show that the rainy season, which is the period with the highest groundwater potential recharge, was from October to May in 2017 and from October to March in 2018. Significant differences between the two analysed years were observed in December 2017 and in April, May, and October 2018. To verify those differences and validate the rainfall data, we compared our data with others rainfall gauges. For the rainfall gauge located in UFSCAR climatological station, low differences were found out $(<5 \mathrm{~mm})$ between the mentioned months. For CHREA-USP
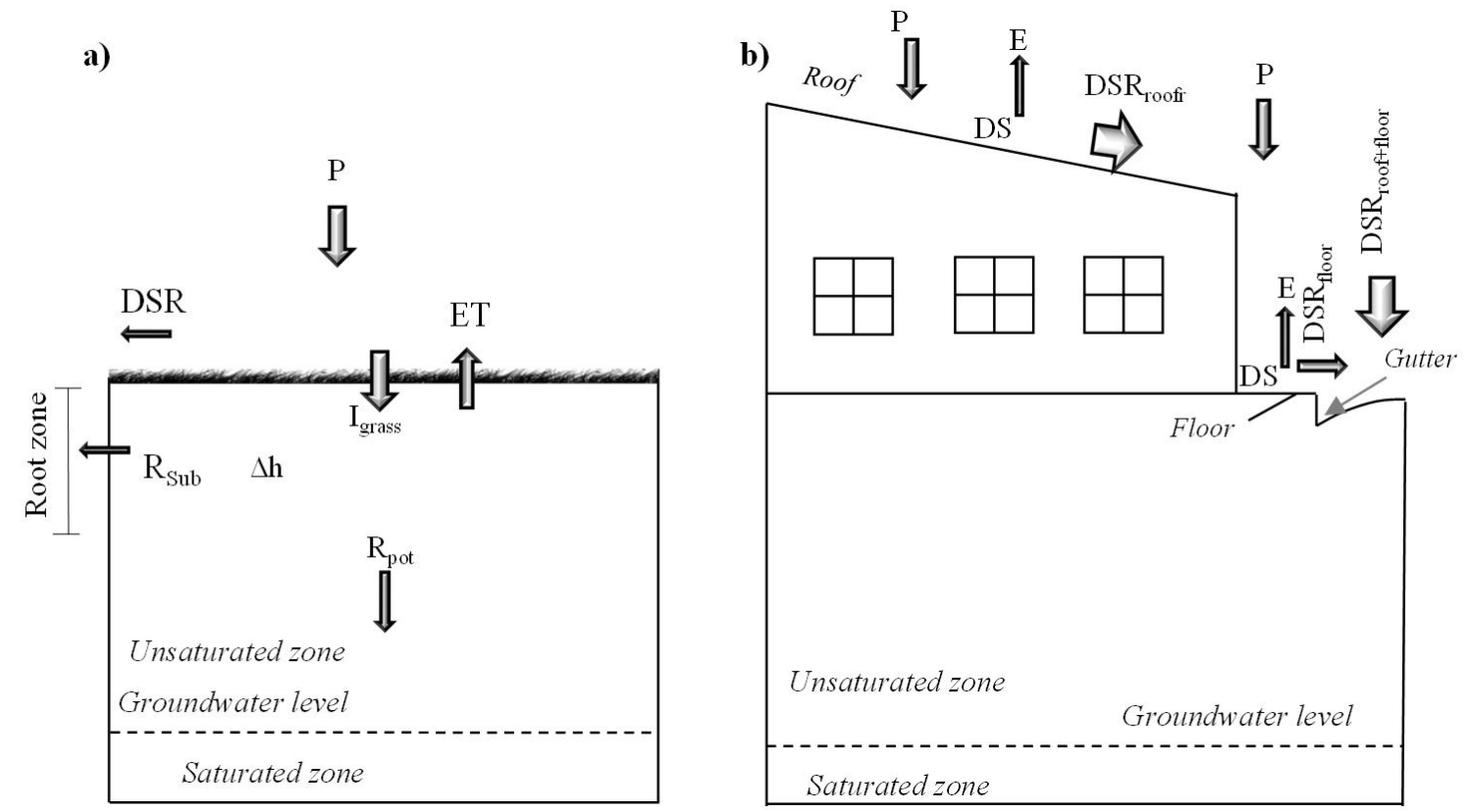

Figure 6. Transverse section of the management schemes of the contribution area with (a) grass cover and (b) drainage traditional system. 


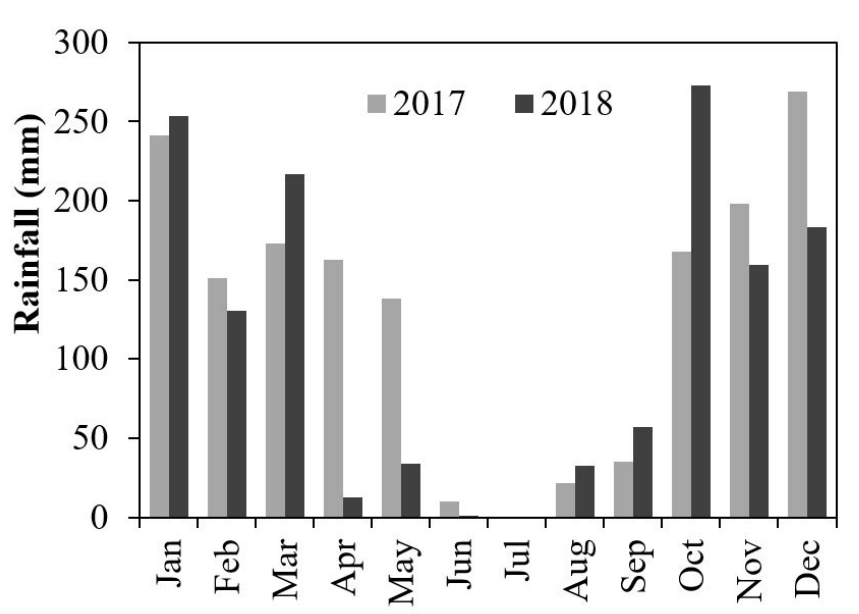

Figure 7. Monthly rainfall data for 2017 and 2018.

climatological station located $20 \mathrm{~km}$ away, were also identified those differences. In terms of annual rainfall, for UFSCAR rain gauge the differences were lower than $10 \mathrm{~mm}$ for both years, and for CHREA station they were low for $2017(25 \mathrm{~mm})$ and slightly high for 2018 (105 mm). These results validate the measured rainfall data, considering that spatial variability in rainfall volumes.

\section{ET estimation}

The $E T_{0}$ values for 2017 and 2018 calculated using Equation 5 were 1172.4 and $1107.3 \mathrm{~mm}$, respectively, which are close values to those obtained by other authors considering similar rainfall volumes. Using a lysimeter, Camargo (1962) found that in Ribeirão Preto, Brazil, located $90 \mathrm{~km}$ away, the ET for grass was $1200 \mathrm{~mm}$ considering a rainfall of $1370 \mathrm{~mm}$. Whereas, Marcuzzo et al. (2008) for São Carlos region, using Class A evaporation pan, obtained an annual $E T_{0}$ of $1214.9 \mathrm{~mm}$ for a $1416.9 \mathrm{~mm}$ rainfall.

With the use of the crop coefficient method that considers the water stress effect, the ET values (Figure 8) were estimated to be 794.2 and $724.2 \mathrm{~mm}$ for 2017 and 2018, respectively. This finding verifies that during the drought period in both years, ET decreased due to water stress effect, indicating a reduced soil water availability and an increased water demand for grass. This result demonstrates the importance of considering water stress coefficient $\left(K_{\mathrm{s}}\right)$ (Figure 8 ) in evapotranspiration variation analysis throughout a year (Abid et al., 2018).

\section{Overflow $\left(\mathrm{O}_{\mathrm{flw}}\right)$}

We used the modified Puls method to determine the drywell $O_{\text {flw }}$ considering $30 \mathrm{~min}$ rainfalls of 9-year return period and PGHidro depth $(2.5 \mathrm{~m})$, and the results are shown in Table 1. To compare the results, we also estimated the $O_{\text {flw }}$ for the events for the 2- and 5-year rainfall return periods considering the depths of the respective designed drywell.

For PGHidro depth and 9-year return period, we found that only Events 1, 2, 3 and 4 were greater than the designed rainfall. However, Event 7 has lower value than design rainfall,

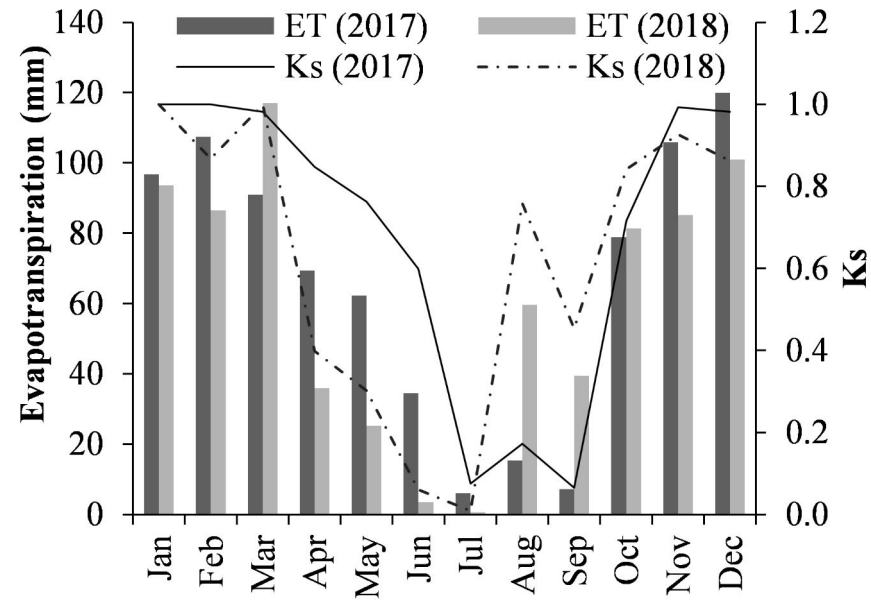

Figure 8. Monthly actual evapotranspiration in 2017 and 2018.

and produced overflow because during $22 \mathrm{~min}$ consecutively of $30 \mathrm{~min}$ rainfall duration, rainfall average intensity was $73 \mathrm{~mm} / \mathrm{h}$, which was intense enough to fill all the PGHidro and generate overflow. The annual $\mathrm{O}_{\text {flw }}$ in any of the analysed years did not exceed $16.2 \mathrm{~mm}$, which is considered low because represents less that $1.2 \%$ of total rainfall. For the 2 -year rainfall return period and drywell depth of $1.75 \mathrm{~m}$, eight rainfall events presented intensity higher than the designed rainfall, and the annual $\mathrm{O}_{\text {flw }}$ for 2017 and 2018 was respectively $26.8 \mathrm{~mm}$ and $44.8 \mathrm{~mm}$, in other words is 1.8 and 2.6 times higher than the drywell with $2.5 \mathrm{~m}$ depth and rainfall events of 9 years return period.

This analysis shows the importance of correct designing of drywells, because permits to increase $\mathrm{R}_{\text {pot }}$ and reduce the $\mathrm{O}_{\text {flw }}$ that is directed to conventional drainage system. However, several Brazilian cities where it is mandatory to implement compensatory techniques, such as São Carlos, the designing process is only based on volume per meter of impervious and rainfall characteristics, which can raise the construction cost due to oversizing of the drywell. To avoid this problem, it is essential consider soil infiltration rates because this variable allows to design a suitable drywell depth and reduces construction cost (Massman, 2004), resulting in increased $\mathrm{R}_{\mathrm{pot}}$ and decreased $\mathrm{O}_{\mathrm{flw}}$. An example to demonstrate the importance of infiltration characteristics can be observed in a soil with low infiltration rates, which presents a soil with clayey texture, compacted surface layer, low percentage of macroporosity and preferential paths, to infiltrate the same volume of a sandy soil with high infiltration capacity during a rainfall event, the drywell must be bigger to compensate it.

\section{Groundwater potential recharge $\left(\mathbf{R}_{\text {pot }}\right)$}

Figure $9 \mathrm{a}, 9 \mathrm{~b}, 9 \mathrm{c}$ and $9 \mathrm{~d}$ show the estimated $\mathrm{R}_{\text {pot }}$ from the water budget equation for rainwater management with the PGHidro (Figure 9a and 9b) designed for rainfall events of 9-year return period and with a grass cover (Figure 9c and 9d), including the water budget components obtained for 2017 and 2018.

Considering the drywell management and the designed rainfall for 9 -year return period, the $R_{\text {pot }}$ shown in Figure $9 \mathrm{a}$ and $9 \mathrm{~b}$, reached 
Table 1. Estimated drywell overflow for different rainfall events for the 9-, 5-, and 2-year rainfall return periods.

\begin{tabular}{|c|c|c|c|c|c|c|}
\hline Event & Month / year & $\begin{array}{l}\text { Intensity } \\
(\mathrm{mm} / \mathrm{h})\end{array}$ & $\begin{array}{c}\text { Total Rainfall } \\
(\mathrm{mm})\end{array}$ & $\begin{array}{c}\text { Direct surface } \\
\text { runoff }(\mathrm{mm})\end{array}$ & $\begin{array}{c}\text { Return period } \\
\text { (Year) }\end{array}$ & Overflow (mm) \\
\hline \multirow[t]{3}{*}{1} & $04 / 17$ & 77.7 & 38.9 & 35.0 & 9 & 9.8 \\
\hline & & & & & 5 & 11.8 \\
\hline & & & & & 2 & 16.2 \\
\hline \multirow[t]{3}{*}{2} & $12 / 17$ & 64.5 & 32.3 & 29.0 & 9 & 4.6 \\
\hline & & & & & 5 & 6.5 \\
\hline & & & & & 2 & 10.6 \\
\hline \multirow[t]{3}{*}{3} & $03 / 18$ & 61.0 & 30.5 & 27.4 & 9 & 3.2 \\
\hline & & & & & 5 & 5.1 \\
\hline & & & & & 2 & 9.1 \\
\hline \multirow[t]{3}{*}{4} & $10 / 18$ & 82.3 & 41.1 & 37.0 & 9 & 11.6 \\
\hline & & & & & 5 & 13.7 \\
\hline & & & & & 2 & 18.1 \\
\hline \multirow[t]{3}{*}{5} & $01 / 18$ & 49.3 & 24.6 & 22.2 & 9 & 0.0 \\
\hline & & & & & 5 & 0.8 \\
\hline & & & & & 2 & 4.4 \\
\hline \multirow[t]{3}{*}{6} & $03 / 18$ & 46.2 & 23.1 & 20.8 & 9 & 0.0 \\
\hline & & & & & 5 & 0.0 \\
\hline & & & & & 2 & 3.2 \\
\hline \multirow[t]{3}{*}{7} & $11 / 18$ & 55.9 & 27.9 & 25.1 & 9 & 1.4 \\
\hline & & & & & 5 & 3.2 \\
\hline & & & & & 2 & 7.0 \\
\hline \multirow[t]{3}{*}{8} & $12 / 18$ & 45.7 & 22.9 & 20.6 & 9 & 0.0 \\
\hline & & & & & 5 & 0.0 \\
\hline & & & & & 2 & 3.0 \\
\hline
\end{tabular}

Obs: Considering rainfall with 30 minutes duration and return period of 9, 5 and 2 years, based on Envelop method (Urbonas \& Stahre, 1993), the calculated intensity $(\mathrm{mm} / \mathrm{h})$, rainfall $(\mathrm{mm})$ and drywell depth $(\mathrm{m})$ are respectively: (59.7/29.8/2.50); (53.1/26.5/2.25) and (44.2/22.1/1.75).
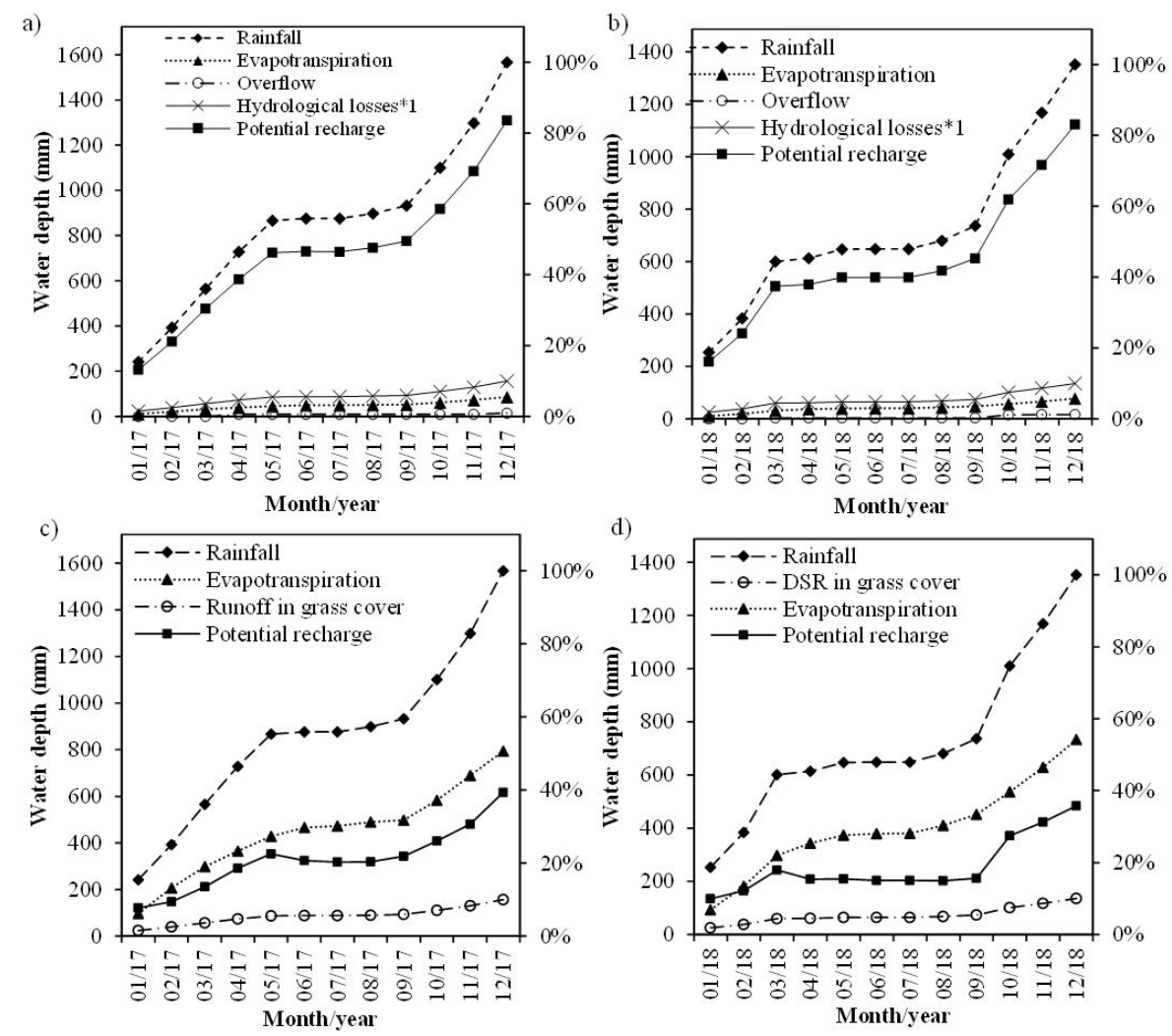

Figure 9. Water budget components in 2017 and 2018 for rainwater management with drywell (a and b) designed for a 9-year rainfall return period and covered with grass $(\mathrm{c}$ and $\mathrm{d}) * 1$ Initial hydrological losses that occur in roof and cemented floor and direct surface runoff in the drywell influence area. 
values higher than $1000 \mathrm{~mm}$ in both analysed years. This is due to the great amount of DSR generated in the impervious contribution area, which almost infiltrated entirely by the PGHidro because of the high soil infiltration rates. Moreover, evapotranspiration was restricted to the small influence area of PGHidro, $O_{\text {flw }}$ do not present significantly values, on the impervious contribution area (roof and cemented floor), the hydrological losses were low and as well as DSR ${ }_{\text {grass }}$

It is important to point that the approximations considered in the conceptual model leaded to overestimation of the predicted values of groundwater recharge. The effect of such assumptions on the accuracy of groundwater recharge estimation were associated to the area that occur evapotranspiration, which can be greater than the considered one that will result in increasing of evapotranspiration. We also assumed that practically does not occur subsurface flow, however this assumption was based in one drilling log, disregarding the soil heterogeneity in other directions, which can present clay or compacted layers increasing $\mathrm{R}_{\text {sub }}$. For $\mathrm{DSR}_{\text {roof }+ \text { floor }}$, were adopted a high runoff coefficient, which $90 \%$ of total rainfall becomes DSR, which despite being a reasonable value due to metal roof and cemented floor conditions, the coefficient runoff were not determined and evaluated directly. If both roof and floor were evaluated directly or DSR were measured by a flow meter, probably DSR ${ }_{\text {roof }+ \text { floor }}$ will be different. Meanwhile, for grass coefficient runoff it was also adopted a value in function of study area grass conditions, however it was not possible to evaluate soil heterogeneity around the PGHidro, thus infiltration rates can be higher or lower, effecting on DSR grass $^{\circ}$ On the other hand, the low overflow values were reasonable because PGHidro have big dimensions and high infiltration rates, which were a strong indicative that overflow will be low.

To compare imperviousness of contribution area, Figure $10 \mathrm{a}$ and $10 \mathrm{~b}$ show the $R_{\text {pot }}$ estimated for $0 \%, 60 \%, 80 \%$, and $100 \%$ of surface imperviousness for 2017 and 2018, respectively. For $0 \%$ imperviousness, ET occurs entirely along the contribution area, significantly reducing the amount of water available for groundwater recharge. However, for $100 \%$ imperviousness, all of the DSR is directed to the drywell and thus can be infiltrated; due to the drastic reduction of permeable area, ET significantly decreased. Conversely, by increasing the impervious area, the potential recharge increases.

The $R_{\text {pot }}$ for natural management (contribution area covered with grass) was below $350 \mathrm{~mm}$ for both years (Figures 9c and 9d). In this scenario, even that infiltrate a great volume of rainfall, ET occurs in the entire contribution area, thus evapotranspiration values increases, resulting in a reduced water availability for potential groundwater recharge.

Table 2 and Table 3 show the percentage of the accumulated values of the water budget components for the years 2017 and 2018, respectively, considering the three analysed rainwater managements: drywell, grass covered area and conventional drainage system managements.

With drywell management, the average $R_{\text {pot }}$ for both years was $83.3 \%$, whereas the average recharge for the contribution area with grass cover did not exceed $37.5 \%$, which represents $2.22 \mathrm{R}_{\text {pot }}$ less than the drywell. This result demonstrates the great contribution of drywells in groundwater recharge.

In the conventional management, the impervious area practically prevented the water from infiltrating the soil and thus evapotranspiration and $R_{\text {pot }}$ were practically null.

Sírio (2014) in the same soil type and located $100 \mathrm{~m}$ away from the PGHidro, modelled a filter-trench system using Hydrus $2 \mathrm{D}$; the $R_{\text {pot }}$ is $45 \%$ of the total rainfall, corresponding to nearly half of the value found in the present study. This difference in $R_{\text {pot }}$ is attributed to the size of the grass influence area of the filter-trench system, which is 16 times larger than the PGHidro influence area, resulting in a greater evapotranspiration, the main cause of soil water loss.

Snyder et al. (1994), Gobel et al. (2004), Endreny \& Collins (2009), Thomas \& Vogel (2012), and Newcomer et al. (2014) found out that in other regions where different compensatory techniques were employed, where different groundwater recharge estimation methods were used, and where there are different imperviousness percentage or soil characteristics, the use of
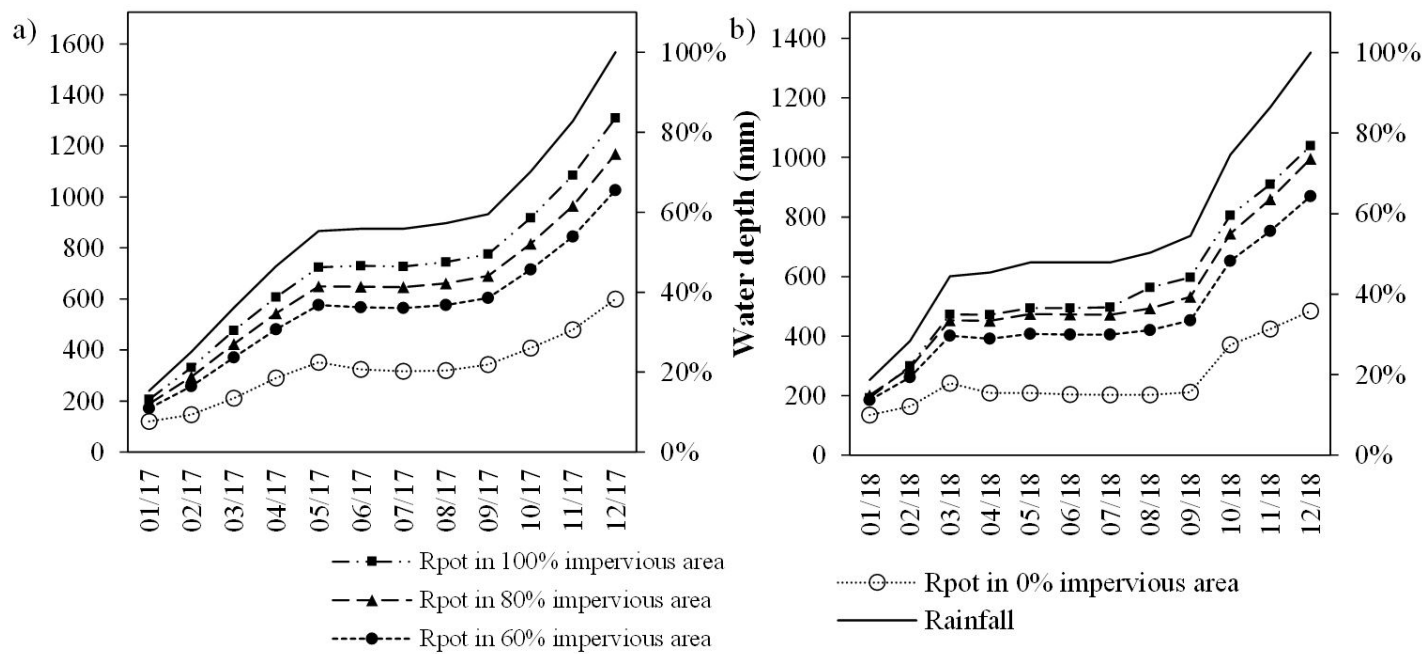

Figure 10. Potential groundwater recharge as a function of the imperviousness of the drywell contribution area for the 9-year return period. 
Table 2. Percentage values of water budget components for different rainwater managements for the 9-, 5-, and 2-year rainfall return periods.

\begin{tabular}{|c|c|c|c|c|c|}
\hline \multirow{4}{*}{ Management } & \multicolumn{5}{|c|}{2017} \\
\hline & \multicolumn{3}{|c|}{ Drywell } & \multirow{3}{*}{ Grass area } & \multirow{3}{*}{$\begin{array}{l}\text { Conventional } \\
\text { system }\end{array}$} \\
\hline & \multicolumn{3}{|c|}{ Return period (year) } & & \\
\hline & 9 & 5 & 2 & & \\
\hline Evapotranspiration (\%) & 5.5 & 5.5 & 5.5 & 50.7 & 0.0 \\
\hline Potential recharge (\%) & 83.6 & 83.3 & 82.6 & 39.3 & 0.0 \\
\hline Overflow $(\%)$ & 0.9 & 1.2 & 1.8 & - & - \\
\hline Direct surface runoff $(\%)$ & - & - & - & 10.0 & $90.0^{*} 2$ \\
\hline Hydrological losses (\%) & 10.0 & 10.0 & 10.0 & - & - \\
\hline
\end{tabular}

*1 Initial hydrological losses that occur in roof and cemented floor and direct surface runoff in the drywell influence area $* 2$ Admitted initial hydrological losses of $10 \%$.

Table 3. Percentage values of water budget components for different rainwater managements for the 9-, 5-, and 2-year rainfall return periods.

\begin{tabular}{|c|c|c|c|c|c|}
\hline \multirow{4}{*}{ Management } & \multicolumn{5}{|c|}{2018} \\
\hline & \multicolumn{3}{|c|}{ Drywell } & \multirow{3}{*}{ Grass area } & \multirow{3}{*}{$\begin{array}{l}\text { Conventional } \\
\text { system }\end{array}$} \\
\hline & \multicolumn{3}{|c|}{ Return period (year) } & & \\
\hline & 9 & 5 & 2 & & \\
\hline Evapotranspiration (\%) & 5.7 & 5.7 & 5.7 & 54.2 & 0.0 \\
\hline Potential recharge $(\%)$ & 83.0 & 82.6 & 80.9 & 35.8 & 0.0 \\
\hline Overflow (\%) & 1.2 & 1.6 & 3.4 & - & - \\
\hline Direct surface runoff $(\%)$ & - & & & 10.0 & $90.0^{*} 2$ \\
\hline Hydrological losses (\%) & 10.0 & 10.0 & 10.0 & - & - \\
\hline
\end{tabular}

compensatory techniques increases the $R_{\text {pot }}$. Using water budget, Snyder et al. (1994) in Portland basin $\left(3,366 \mathrm{~km}^{2}\right)$ considering 5700 drywells located in urban area, estimated that $75 \%$ of the rainfall contributes to the $R_{\text {pot }}$. Gobel et al. (2004) simulated a swale trench using Hydrus $2 \mathrm{D}$ and obtained an $R_{\text {pot }}$ of $42 \%$. By using a bioretention basin from the combination of PCSWMM and MODFLOW software, Endreny \& Collins (2009) found an increase in average groundwater mounding from $0.28 \mathrm{~m}$ to $0.72 \mathrm{~m}$. Moreover, Thomas \& Vogel (2012) developed a regional multivariate regression model to determine the effects of BMPs in groundwater level, revealing that those BMPs exert a small but significant positive effect on groundwater elevations. Considering an infiltration trench and an irrigated lawn, Newcomer et al. (2014) simulated groundwater recharge using water budget, Hydrus 2D and, Darcy method, and they obtained an average $\mathrm{R}_{\text {pot }}$ of $72.6 \%$ and $23.3 \%$ respectively. Besides showing the importance of compensatory techniques in groundwater recharge, these results highlight the contribution of drywell in increasing $R_{\text {pot }}$.

Although the infiltration drywell has shown good efficiency promoting potential groundwater recharge, it is necessary to consider its periodic maintenance. Since the geotextile clogging does not allow water to infiltrate in the soil. In this work, we did not carry a specific analysis on the geotextile permeability, but considering that during the water level monitoring period of the PGHidro there was no overflow, it means that there was no geotextile clogging and that even with reduced permeability, the direct surface runoff continued to infiltrate the soil, which did not interfere in the Rpot. Ferreira (2016) analyzed the geotextile permeability with mass per unit area of $400 \mathrm{~g} / \mathrm{m}^{2}$ installed in PGHidro after 27 months of operation. This author verified that the bottom geotextile showed a permeability reduction of $82 \%$ in relation to the geotextile permeability at the start of the operation and the cap geotextile had 63\% reduction. Nevertheless, the geotextile permeability was still greater than the soil's permeability, which did not limit soil infiltration capacity. Barbassa et al. (2014) found that in the 8-month period of operation of an drywell similar to PGHidro, there was a $51 \%, 8 \%$ and $22 \%$ reduction in the geotextile permeability, considering the bottom, side and cover of the drywell, respectively.

\section{CONCLUSIONS}

Using the water budget equation, the average $R_{\text {pot }}$ was estimated to be $83.4 \%$ of the total rainfall for the rainwater management that considers the DSR is directed to a drywell and contribution area consisting of a roof and a cemented floor.

The same contribution area but now covered with grass and without a drywell generated an average $R_{\text {pot }}$ of $37.5 \%$. Therefore, $R_{\text {pot }}$ for drywell management is 2.22 times higher than that for the area covered with grass. This result was obtained because the drywell infiltrated almost all of the DSR generated in the impervious contribution as well as reduced the area available for evapotranspiration. Thus, the drywell increased the potential recharge from the runoff generated by the impervious contribution area.

By contrast, conventional management practically did not result in potential recharge. All of the DSR generated in the impervious area, approximately $90 \%$ of the total rainfall, was directed to the drainage system, and the remainder represented hydrological losses through retention and evaporation. 
Based on those results it was verified that rainwater management using drywells contributes significantly to groundwater recharge, although site-specific soil characteristics should be taken into account both to drywell dimensioning and groundwater recharge estimation. In order to dimension drywell with a higher efficiency is essential to consider soil type, which is not considered in Brazilian standards, because for soils with high infiltration rates it is not necessary large drywell dimensions so it does not occur overflow. In other words, soil infiltration rates should be incorporated in drywell dimensioning methods in order to reduce drywell costs.

Moreover, the water budget method for potential recharge estimation is easy to use and presents good results, although it warrants monitoring of several hydrological variables.

\section{ACKNOWLEDGMENTS}

This study was funded by the Financial Agency of Studies and Projects (Financiadora de Estudos e Projetos) [No. 1827/10].

\section{REFERENCES}

Abid, N., Bargaoui, Z., \& Mannaerts, C. M. (2018). Remote-sensing estimation of the water stress coefficient and comparison with drought evidence. International Journal of Remote Sensing: Advances in Remote Sensing Applications in Silvo-Pastoral Systems, 39(14), 46164639. https://doi.org/10.1080/01431161.2018.1430917.

Ahiablame, L. M., Engel, B. A., \& Chaubey, I. (2012). Effectiveness of low impact development practices: literature review and suggestions for future research. Water, Air, and Soil Pollution, 7(223), 4253-4273. http://dx.doi.org/10.1007/s11270-012-1189-2.

Allen, R. G., Pereira, L. S., Raes, D., \& Smith, M. (1998). Crop e evapotranspiration: Guidelines for computing crop water requirements (FAO - Irrigation and Dranage Paper, Paper 56, 300 p.). Rome: FAO.

American Society of Civil Engineers - ASCE. (1992). Design and construction of urban stormwater management systems. New York: ASCE.

Associação Brasileira de Normas Técnicas - ABNT NBR 13292. (1995). Solo - Determinação do coeficiente de permeabilidade de solos granulares à carga constante. Rio de Janeiro: ABNT.

Barbassa, A. P. (1991). Simulação do efeito da urbanização sobre a drenagem pluviail na cidade de São Carlos-SP (Tese de doutorado). Escola de Engenharia de São Carlos, Universidade de São Paulo, São Carlos.

Barbassa, A. P., Angelini Sobrinha, L., \& Moruzzi, R. B. (2014). Poço de infiltração para controle de enchentes na fonte: avaliação das condições de operação e manutenção. Ambiente Construído, (14), 91-107. Retrieved in 2019, September 2, from https:/ / www.scielo. $\mathrm{br} / \mathrm{pdf} / \mathrm{ac} / \mathrm{v} 14 \mathrm{n} 2 / 07 . \mathrm{pdf}$

Beekman, H. E., \& Xu, Y. (2003). Review of groundwater recharge estimation in arid and semi-arid Southern Africa. In Y. Xu \& H. E. Beekman (Eds.), Grundwater recharge estimation in Southern Africa (chap. 1, pp. 5-15). Paris: UNESCO.
Bogino, S. (2014). The centenary pluviometer: a pioneer dendrochronological study in South America. Dendrochronologia, 32(1), 52-54. http://dx.doi.org/10.1016/j.dendro.2013.08.001.

Camargo, A. P. (1962). Contribuição para a determinação da evapotranspiração potencial no Estado de São Paulo. Bragantia, 21(12), 163-213. Retrieved in 2019, August 22, from https:/ / www.scielo. br/scielo.php?script=sci_arttext\&pid=S0006-87052000000200002

Carvalho, E. T. L. (2008). Avaliação de elementos de águas pluviais na Zona Norte de Goiânia (Dissertação de mestrado). Escola de Engenharia Civil, Universidade Federal de Goiás, Goiânia. Retrieved in 2019, September 10, from http:/ / repositorio.bc.ufg.br/tede/ handle/tede/5711

Carvalho, E. T. L. (2013). Avaliação geotécnica de poços de infiltração de águas pluviais (Tese de doutorado). Departamento de Engenharia Civil e Ambiental, Universidade de Brasília, Brasília. Retrieved in 2019, September 20, from https://repositorio.unb.br/ handle/10482/15071

Centro de Pesquisas Meteorológicas e Climáticas Aplicadas à Agricultura - CEPAGRI. (2018). Climate monitoring. Retrieved in 2019, November 10, from http://www.cpa.unicamp.br/outrasinformacoes/clima_muni_068.html

Christians, N. E. (1998). Fundamental of turfgrass management (1st ed., 312p.). John Wiley \& Sons.

Cudworth Júnior, A. G. (1989). Flood bydrology manual: a water resources technical publication. Denver: United States Government Printing Office.

Delle Rose, M., Fidelibus, C., \& Martano, P. (2018). Assessment of specific yield in karstified fractured rock through the waterbudget method. Geosciences, 8(9), 344. http://dx.doi.org/10.3390/ geosciences 8090344 .

Doorenbos, J., \& Pruitt, W. (1997). Crop water requirements (Paper 24). Rome: FAO.

Edwards, E. C., Harter, T., Fogg, G. E., Washburn, B., \& Hamad, H. (2016). Assessing the effectiveness of drywells as tools for stormwater management and aquifer recharge and their groundwater contamination potential. Journal of Hydrology, 539, 539-553. http:/ / dx.doi.org/10.1016/j.jhydrol.2016.05.059.

Endreny, T., \& Collins, V. (2009). Implications of bioretention basin spatial arrangements on stormwater recharge and groundwater mounding. Ecological Engineering, 35(5), 670-677. http://dx.doi. org/10.1016/j.ecoleng.2008.10.017.

Failache, M. F., \& Zuquette, L. V. (2018). Geological and geotechnical land zoning for potential Hortonian overland flow in a basin in southern Brazil. Engineering Geology, 246, 107-122. http://dx.doi. org/10.1016/j.enggeo.2018.09.032. 
Feng, Y., Burian, S., \& Pomeroy, C. (2016). Potential of green infrastructure to restore predevelopment water budget of a semi-arid urban catchment. Journal of Hydrology (Amsterdam), 542, 744-755. http://dx.doi.org/10.1016/j.jhydrol.2016.09.044.

Ferreira, T. S. (2016). Avaliação do comportamento bidrológico de poços de infiltração de águas pluviais sob diferentes concepções (Dissertação de mestrado). Centro de Ciências Exatas e de Tecnologia, Universidade Federal de São Carlos, São Carlos. Retrieved in 2019, December 15, from https://repositorio.ufscar.br/handle/ufscar/7951

Ferreira, T. S., Barbassa, A. P., \& Moruzzi, R. B. (2018). Controle de enchentes no lote por poço de infiltração de água pluviais sob nova concepção. Engenharia Sanitaria e Ambiental, 23(3), 437-446. http://dx.doi.org/10.1590/S1413-41522018161116.

Fetter, C. W. (2001). Applied bydrogeology (4th ed., 598 p.). USA: Prentice-Hall, Inc.

Fletcher, T., Shuster, W., Hunt, W., Ashley, R., Butler, D., Arthur, S., Trowsdale, S., et al.(2015). SUDS, LID, BMPs, WSUD and more - The evolution and application of terminology surrounding urban drainage. Urban Water Journal, 12(7), 525-542. http:/ / dx.doi. org/10.1080/1573062X.2014.916314.

Gobel, P., Stubbe, H., Weinert, M., Zimmernann, J., Stefan, F., Dierkes, C., Kories, H., Messer, J., Mertsch, V., Geiger, W. F., \& Coldewey, W. G. (2004). Near-natural stormwater management and its effects on the water budget and groundwater surface in urban areas taking account of the hydrogeological conditions. Journal of Hydrology (Amsterdam), 299(3-4), 267-283. http://dx.doi. org/10.1016/j.jhydrol.2004.08.013.

Granata, F., Gargano, R., \& de Marinis, G. (2020). Artificial intelligence based approaches to evaluate actual evapotranspiration in wetlands. The Science of the Total Environment, 703, 135653.

Hellman, K., Wagner, J., Lass, D., Korfmacher, K., \& Gleeson Hanna, B. (2018). Estimating the economic impact of stormwater runoff in the allen creek watershed. Ecological Economics, $145 \mathrm{C}$, 420-429. http://dx.doi.org/10.1016/j.ecolecon.2017.11.022.

Hofmann, M., Lux, R., \& Schultz, H. R. (2014). Constructing a framework for risk analyses of climate change effects on the water budget of differently sloped vineyards with a numeric simulation using the Monte Carlo Method coupled to a water balance model. Eschultz Frontiers in Plant Science, 10(5), 645. http:/ / dx.doi.org/10.3389/fpls.2014.00645.

Instituto Brasileiro de Geografia e Estatistica - IBGE. (2012). Brazilian economical and social profile. Rio de Janeiro: IBGE. Retrieved in 2019, April 17, from https://ww2.ibge.gov.br/home/estatistica/ economia/perfilmunic/2012/

Jung, D., \& Kim, J. (2020). Development of a multiscenario planning approach for urban drainage systems. Applied Sciences (Basel, Switzerland), 10(5), 1834. http://dx.doi.org/10.3390/app10051834.
Justino, E. A. (2019). Comportamento bidrodinâmico do solo e da recarga de aquífero a partir a partir de poços de infiltração de águas pluviais (Tese de doutorado). Centro de Ciências Exatas e de Tecnologia, Universidade Federal de São Carlos, São Carlos. Retrieved in 2019, December 15, from https://repositorio.ufscar.br/handle/ufscar/12036

King, R. B. (1992). Overview and bibliography of methods for evaluating the surface-water-infiltration component of the rainfall-overland flow process (Water-Resources Investigations Report, No. 92-4095). Urbana, Illinois: U.S. Geological Survey.

Lerner, D. N., Issar, A. S., \& Simmers, I. (1990). Groundwater recharge: a guide to understanding and estimating natural recharge (Vol. 8). Rotterdan: Balkema.

Libardi, P. L. (2005). Dinâmica da água no solo. São Paulo: EDUSP.

Linsley, R., Kohler, M., \& Paulhus, J. (1982). Hydrology for Engineers (3rd ed., 340p.). USA: McGraw HiII Inc.

Lucas, A. H., Sobrinha, L., Moruzzi, R., \& Barbassa, A. P. (2015). Avaliação da construção e operação de técnicas compensatórias de drenagem urbana: o transporte de finos, a capacidade de infiltração, a taxa de infiltração real do solo e a permeabilidade da manta geotêxtil. Revista Engenharia Sanitária e Ambiental, 20(1), 17-28. http://dx.doi.org/10.1590/S1413-41522015020000079923.

Mai, Y., Zhang, M., Chen, W., Chen, X., Huang, G., \& Li, D. (2018). Experimental study on the effects of LID measures on the control of rainfall runoff. Urban Water Journal, 15(9), 827-836. http://dx.doi.org/10.1080/1573062X.2018.1561912.

Marcuzzo, F. F. N., Arantes, E. J., \& Wendland, E. (2008). Evaluation of potential and direct evapotranspiration estimate methods applied in the region of São Carlos. Irriga Botucatu, 13(3), 323-338. Retrieved in 2019, August 22, from https:/ / www.researchgate.net/ publication/292934062_Evaluation_of_potential_and_direct_ evapotranspiration_estimate_methods_applied_in_the_region_ of_Sao_Carlos-SP_-_AVALIACAO_DE_METODOS_DE_ ESTIMATIVA_DE_EVAPOTRANSPIRACAO_POTENCIAL_E_ DIRETA_PARA_A_REGIAO

Massman, J. (2004). An approach for estimating infiltration rates for stormwater infiltration dry wells. (Technical report). Washington: Washington State Department of Transportation.

Morel-Seytoux, H. J. (1988). Soil-aquifer-stream interactions - a reductionist attempt toward physical-stochastic integration. Journal of Hydrology (Amsterdam), 102(1-4), 355-379. http://dx.doi. org/10.1016/0022-1694(88)90107-2.

Moruzzi, R., Barbassa, A. P., Correa, T., Gutierrez, A., \& Teixeira, B. (2014). Aedes aegypti proliferation in stormwater retained in Best Management Practices. International Journal of Civil \& Environmental Engineering, 14, 1-6.

Munier, S., \& Aires, F. (2018). A new global method of satellite dataset merging and quality characterization constrained by the 
terrestrial water budget. Remote Sensing of Environment, 205, 119130. http://dx.doi.org/10.1016/j.rse.2017.11.008.

Newcomer, M. E., Gurdak, J. J., Sklar, L. S., \& Nanus, L. (2014). Urban recharge beneath low impact development and effects of climate variability and change. Water Resources Research, 50, 17161734. http://dx.doi.org/10.1002/2013WR014282.

Pejon, O. (1987). Estudos geológico-geotécnicos da região urbana de Araraquara-SP (Dissertação de mestrado). Escola de Engenharia de São Carlos, Universidade de São Paulo, São Carlos.

Petrucci, G., \& Tassin, B. (2015). A simple modelo of flow rate atenuation in sewer systems aplication to urban stormwater source control. Journal of Hydrology (Amsterdam), 522, 534-543. http:// dx.doi.org/10.1016/j.jhydrol.2015.01.012.

Puls, L. G. (1928). Flood regulation of the Tennessee River (House Document, No. 185). Washington: U.S. Government Printing Office.

Reis, R. P. A., Oliveira, L. H., \& Sales, M. M. (2008). Sistemas de drenagem na fonte por poços de infiltração de águas pluviais. Ambiente Construido, 8(2), 99-117. Retrieved in 2019, July 2, from https:// seer.ufrgs.br/ambienteconstruido/article/viewFile/5361/3286

Reis, R., \& Ilha, M. S. O. (2014). Comparação de desempenho hidrológico de sistemas de infiltração de água de chuva: poço de infiltração e jardim de chuva. Ambiente Construido, 14(2), 79-90. http:/ /dx.doi.org/10.1590/S1678-86212014000200006.

Rodio, S. A. (1965). Mesures des permeabilites en place. Paris: Association pour l'organisation des stages en France. Cooperation Technique. Stage de Perfectionnement, Geoconseil.

Rushton, K. R. (1988). Numerical and conceptual models for recharge estimation in arid and semi-arid zones. In I. Simmers (Ed.), Estimation of natural groundwater recharge (chap. 14). Amsterdan: Reidel Publishing.

Salemi, L. F. (2013). Escoamento sub-superficial de água: em qual profundidade do solo? WebArtigos. Retrieved in 2019, February 2, from http://webartigos.com/artigos/escoamento-sub-superficialde-agua-em-qual-profundidade-no-sub-solo/102467

São Carlos. (2011). Lei no 15.958 de 29 de dezembro de 2011. Dispõe sobre o Código de Obras e Edificações do Município de São Carlos, e dá outras. Diário Oficial do Município, São Carlos.

Sasidharan, S., Bradford, S., Simunek, J., Dejong, B., \& Kraemer, S. (2018). Evaluating drywells for stormwater management and enhanced aquifer recharge. Advances in Water Resources, 116, 167177. http://dx.doi.org/10.1016/j.advwatres.2018.04.003.

Scanlon, R. B., \& Cook, P. G. (2002). Theme issue: groundwater recharge. Hydrogeology Journal, 10(1), 18-39. http://dx.doi.org/10.1007/ s10040-006-0120-6.

Schwartz, R. C., Evett, S. R., Anderson, S. K., \& Anderson, D. J. (2016). Evaluation of a direct-couple time-domain reflectometry for determination of soil water content and bulk electrical conductivity. Vadose Zone Journal, 15(1), 1-8. http://dx.doi. org/10.2136/VZJ2015-08.0115.

Sharma, M. L. (1986). Measurement and prediction of natural groundwater recharge - an overview. Journal of Hydrology (Amsterdam), 25(1), 49-56.

Shon, T. S., Kim, M. E., Joo, J. S., Jo, D. J., \& Shin, H. S. (2013). Analysis of the characteristics of non-point pollutant runoff applied LID techniques in industrial area. Desalination and Water Treatment, 51(19-21), 4107-4117. http://dx.doi.org/10.1080/19 443994.2013.781107.

Silva, A., Nascimento, N., Seidl, M., \& Vieira, L. (2010). WITCH in Belo Horizonte, Brazil: infiltration and detention systems for more sustainable stormwater control in Belo Horizonte. Reviews in Environmental Science and Biotechnology, 9(1), 7-13. http://dx.doi. org/10.1007/s11157-010-9196-5.

Sírio, D. L. M. (2014). Monitoramento e modelagem de recarga em técnica de drenagem compensatória (Dissertação de mestrado). Universidade Federal de São Carlos, São Carlos. Retrieved in 2019, September 30, from https:/ / repositorio.ufscar.br/handle/ufscar/4371?show=full

Snyder, D. T., Morgan, D. S., \& McGrath, T. S. (1994). Estimation of groundwater recharge from precipitation, runoff into drywells, and onsite waste-disposal systems in the Portland Basin, Oregon and Washington (Water-Resources Investigations Report, No. 92-4010, pp. 1-24). Portland: U.S. Geological Survey.

Sonaje, N. (2013). Modelling of infiltration process. Indian Journal of Applied Research, 3(9), 226-230. http://dx.doi.org/10.15373/2249555X/ SEPT2013/69.

Soubie, R., Heinesch, B., Granier, A., Aubinet, M., \& Vincke, C. (2016). Evapotranspiration assessment of a mixed temperate forest by four methods: eddy covariance, soil water budget, analytical and model. Agricultural and Forest Meteorology, 228-229, 191-204. Retrieved in 2019, September 30, from http:/ / hdl.handle.net/2268/236366

Tavares, L. P. S., Lugon Junior, J., Da Silva, J. A. F., Wasserman, J. C., \& Rodrigues, P. P. G. W. (2018). Water management and urban flood mitigation: studies and proposals for the Macaé River Basin In Brazil. Journal of Urban and Environmental Engineering, 12(2), 188-200. http://dx.doi.org/10.4090/juee.2018.v12n2.188200.

Tecedor, N., Barbassa, A. P., Moruzzi, R., \& Gonçalves, L. M. (2015). Monitoramento e modelagem hidrológica de plano de infiltração construído em escala real. Revista Brasileira de Recursos Hídricos, 20(3), 594-604.

Thomas, B., \& Vogel, R. (2012). Impact of storm water recharge practices on boston groundwater elevations. Journal of Hydrologic Engineering, 17(8), 923-932. http://dx.doi.org/10.1061/(ASCE) HE.1943-5584.0000534.

Urbonas, B., \& Stahre, P. (1993). Stormwater best a managemente practices and detetion. New Jersey: Prentice Hal. 
Wang, S., \& Wang, H. (2018). Extending the rational method for assessing and developing sustainable urban drainage systems. Water Research, 144, 112-125. http://dx.doi.org/10.1016/j. watres.2018.07.022.

Wang, S., Huang, J., Li, J., Rivera, A., McKenney, D. W., \& Sheffield, J. (2014). Assessment of water budge for sixteen large drainage basins in Canada. Journal of Hydrology (Amsterdam), 512, 1-15. http://dx.doi.org/10.1016/j.jhydrol.2014.02.058.

Wang, Y., \& Yang, X. W. (2018). Sensitivity analysis of the surface runoff coefdicient of HiPIMS in simulating flood processes in a Large Basin. Water (Basel), 10(3), 253. http:/ / dx.doi.org/10.3390/ w10030253.

Ward, A., \& Trimble, S. (2003). Environmental bydrology (2nd ed., 475 p.). Boca Raton: Lewis Publishers.

\section{Authors contributions}

Eliane Aparecida Justino: Conceptualization, data collected, calculations, with the exception of the Modified Puls Method, writing - formal analysis, writing - review and editing.

Moisés Furtado Failache: Conceptualization, llustrations, writing - formal analysis, writing - review and editing, visualization and supervision.

Ademir Paceli Barbassa: Modified Puls Method calculations, writing - formal analysis, writing - review and editing, visualization and supervision.

Editor-in-Chief: Adilson Pinheiro

Associated Editor: Carlos Henrique Ribeiro Lima 